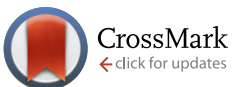

Cite this: Lab Chip, 2015, 15, 1574

Received 29th December 2014, Accepted 19th January 2015

DOI: $10.1039 / c 4 l c 01510$

www.rsc.org/loc

\section{HIV microarray for the mapping and characterization of HIV-specific antibody responses $\dagger$}

\author{
Daniela Gallerano, $\ddagger^{\mathrm{a}}$ Eva Wollmann $\star^{\mathrm{a}}$ Christian Lupinek, $\ddagger^{\mathrm{a}}$ Thomas Schlederer, $\star^{\mathrm{b}}$

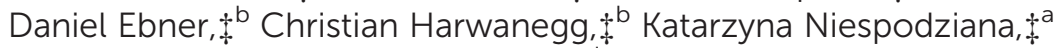

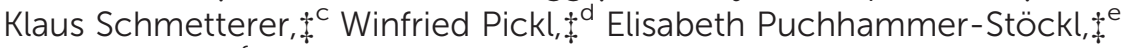 \\ Elopy Sibanda $f^{f}$ and Rudolf Valenta *a
}

\begin{abstract}
We used the microarray technology to develop chips containing a comprehensive set of proteins and peptides covering the proteome of HIV-1 clade C, which is the HIV-1 subtype that causes the majority of infections worldwide. We demonstrate that the HIV microarray allows simultaneous, sensitive and specific detection of antibody responses for the major immunoglobulin classes (IgG, IgA, IgM, IgE) and subclasses $\left(\operatorname{lgG}_{1-4}\right)$ with minute amounts of serum samples towards a large number of HIV antigens and peptides. Furthermore, we show that the HIV chip can be used for the monitoring of antibody responses during the course of the disease and during treatment. The HIV microarray should be useful to study antibody responses to multiple HIV antigens and epitopes in HIV-infected patients to explore pathomechanisms of the disease, for diagnosis and for monitoring of treatment and of vaccine trials.
\end{abstract}

\section{Introduction}

HIV infections represent a major health threat. At present more than 35 million individuals worldwide are infected. ${ }^{1}$ More than $10 \%$ of the HIV-infected persons recorded in the United States were unaware of their infection. ${ }^{2}$ Currently available diagnostic tests for HIV are based on the detection of viral materials such as RNA or proteins and on the detection of HIV-specific antibodies using first line tests with high sensitivity and second line procedures with high specificity. ${ }^{3}$ The identification of new neutralizing antibodies which protect against infection and results obtained from the analysis of

\footnotetext{
${ }^{a}$ Division of Immunopathology, Department of Pathophysiology and Allergy Research, Center for Pathophysiology, Infectiology and Immunology, Medical University of Vienna, Währinger Gürtel 18-20, 3Q, 1090 Vienna, Austria.

E-mail: rudolf.valenta@meduniwien.ac.at; Fax: +43 140400 51300; Tel: +4314040051080

${ }^{b}$ Phadia Austria GmbH, Part of Thermo Fisher Scientific ImmunoDiagnostics, Vienna, Austria

${ }^{c}$ Department of Laboratory Medicine, Medical University of Vienna, Austria

${ }^{d}$ Department of Immunology, Medical University of Vienna, Austria

${ }^{e}$ Department of Virology, Medical University of Vienna, Austria

${ }^{f}$ Asthma, Allergy and Immune Dysfunction Clinic, Parirenyatwa University Teaching Hospital, Harare, Zimbabwe

$\dagger$ Electronic supplementary information (ESI) available. See DOI: 10.1039/ c4lc01510j

\$ Author contributions: DG: conception and design of the study, data generation, analysis and interpretation of the data, preparation and critical revision of the manuscript. EW, CL, TS, DE, CH, KN, KS, WP, EP, ES: data generation and critical revision of the manuscript. RV: conception and design of the study, analysis and interpretation of the data, preparation and critical revision of the manuscript.
}

antibody responses in HIV controllers and HIV vaccine trials indicate that a detailed investigation of antibody responses towards different viral antigens and epitopes may provide new information for the development of new immunological strategies for the treatment and prevention of HIV infections (e.g., antibody-based treatments, vaccines). ${ }^{4-8}$ Evidence for the usefulness of multiplexed antibody analysis in the field of HIV comes from a recent study which analysed antibody responses in HIV-infected patients and subjects who participated in vaccine trials. A comprehensive set of small peptides derived from the virus envelope allowed the identification of antibody signatures that may be associated with protection. ${ }^{9}$

In fact, multiplex immune assays based on micro-arrayed antigens and epitopes are currently revolutionizing the analysis of pathomechanisms as well as the diagnosis of several immunological diseases such as allergy, autoimmunity, infectious diseases and cancer. ${ }^{10-15}$ However, multiplex assays for the analysis of antibody responses against multiple HIVproteins and peptides are not available. Therefore, the aim of this study was the development of an HIV microarray containing a large panel of HIV proteins and peptides for the mapping and characterization of HIV-specific antibody responses towards multiple viral antigens and epitopes with minimal amounts of sample and short assay-duration. For this purpose, we employed the microarray-chip technology which we originally had developed for the diagnosis of allergy (i.e., Immuno solid-phase allergen chip, ISAC). ${ }^{10}$ We prepared a set of HIV proteins and peptides derived from HIV-1 clade $\mathrm{C}$, because this is the HIV-1 subtype that causes the majority of infections worldwide (48\%). HIV-1 clade $\mathrm{C}$ is also the 
subtype that predominates in Sub-Saharan Africa, where the highest rates of infection are reported (4.7\% infected adults) (UNAIDS global report 2013). ${ }^{16}$ We demonstrate that the HIV microarray allowed the measurement of isotypes and IgG subclasses against a comprehensive set of proteins and peptides covering the clade $\mathrm{C}$ proteome.

\section{Materials and methods}

\section{Synthesis, purification and characterization of HIV peptides}

Overlapping peptides covering the amino acid sequence of gp120, gp41, VIF, REV, VPR and VPU from HIV-1 subtype C (isolate ZA.04.04ZASK146, hiv.lanl.gov \#AY772699) were produced by solid-phase synthesis. The peptides were synthesized with the 9-fluorenyl-methoxy-carbonyl (Fmoc)-method (CEM-Liberty, Matthews, NC, USA and Applied Biosystems, Carlsbad, CA, USA) on PEG-PS preloaded resins (Applied Biosystems, Carlsbad, CA, USA). After washing with dichloromethane, peptides were cleaved from the resins in $19 \mathrm{ml}$ trifluoroacetic acid, $0.5 \mathrm{ml}$ silane and $0.5 \mathrm{ml} \mathrm{H}_{2} \mathrm{O}$ and precipitated into pre-chilled tert-butylmethylether. Peptides were purified by reverse-phase HPLC in a 10-70\% acetonitrile gradient using a Jupiter $4 \mu \mathrm{m}$ Proteo $90 \AA ̊$, LC column (Phenomenex, Torrance, CA, USA) and an UltiMate 3000 Pump (Dionex, Sunnyvale, CA, USA) to a purity $>90 \%$. Their identities and molecular weights were verified by mass spectrometry (Microflex MALDI-TOF, Bruker, Billerica, MA, USA).

\section{Expression, purification and characterization of recombinant HIV proteins}

Recombinant gp120 from HIV-1 subtype C was purchased from Sino Biological (Beijing, People's Republic of China). The ectodomain of gp41 from HIV-1 subtype C (isolate ZA.04.04ZASK146, hiv.lanl.gov \#AY772699, amino acids 532-683 numbered accordingly to the HXB2 scheme) was expressed in a human $\mathrm{T}$ cell line (Jurkat E6 cell line) (Wollmann, unpublished data). Recombinant his-tagged structural (matrix, MA; capsid, CA and nucleocapsid, NC), functional (protease, PR; reverse transcriptase + RNaseH, RR and integrase, IN) and accessory proteins (NEF, TAT and VIF) were expressed in $E$. coli. The DNA sequences of MA, CA, NC, PR, NEF, TAT, VIF (HIV-1 clade C isolate ZA.04.04ZASK146, hiv.lanl.gov \#AY772699) and of RR and IN (HIV-1 clade C isolate ET.86.ETH2220, hiv.lanl.gov \#U46016) contained a 3' sequence coding for a C-terminal hexa-histidine tag. Sequences codon-optimized for bacterial expression were cloned into plasmid pET17b, between EcoRI and NdeI restriction sites (ATG:biosynthetics, Merzhausen, Germany). E. coli BL21(DE3) cells (Agilent Technologies, Santa Clara, CA, USA) were transformed and grown to an $\mathrm{OD}_{600}=0.4-0.6$ in $\mathrm{LB}$ medium containing $100 \mathrm{mg} \mathrm{l}^{-1}$ ampicillin. Isopropyl- $\beta$ thiogalactopyranoside $(0.5-1.0 \mathrm{mM})$ was used to induce protein expression and cells were harvested at time-points of maximal expression (i.e. PR: $30 \mathrm{~min}$; MA, CA, RR, IN, NEF, TAT and VIF: $4 \mathrm{~h}$; NC: ON). Recombinant proteins were purified by nickel-affinity chromatography under native
(MA, CA, NC) or denaturing (PR, IN, NEF, TAT) conditions (Qiagen, Hilden, Germany). VIF and RR were purified with an inclusion body preparation protocol. ${ }^{17}$ Stepwise dialysis was used to remove the denaturing agent and to refold the recombinant proteins. The identity of the proteins was verified by SDS-PAGE followed by Coomassie Brilliant Blue staining. In addition, His-tagged proteins were blotted onto Whatman Protran nitrocellulose (GE Healthcare Bio-Sciences, Uppsala, Sweden) and detected with mouse $\alpha$-His IgG $\left(0.2 \mu \mathrm{g} \mathrm{ml}{ }^{-1}\right)$ (Dianova, Hamburg, Germany) followed by incubation with alkaline-phosphatase-labelled rabbit $\alpha$-mIgG $\left(0.5 \mu \mathrm{g} \mathrm{ml}^{-1}\right)(\mathrm{BD}$, Franklin Lakes, NJ, USA). Mass spectrometry was performed to verify the molecular mass of recombinant proteins (Microflex MALDI-TOF, Bruker). The secondary structure of the proteins was measured by circular dichroism spectroscopy on a Jasko J-810 spectropolarimeter (Japan Spectroscopic, Tokyo, Japan) at a protein concentration of $0.1 \mathrm{mg} \mathrm{ml}^{-1}$ in $10 \mathrm{mM}$ sodiumphosphate. ${ }^{17}$ The biochemical properties of the recombinant HIV proteins were calculated from their amino acid sequence with ProtParam (http://web.expasy.org/protparam/).

\section{Control proteins, labelling of detection antibodies and spotting of the HIV microarray}

Human serum albumin (HSA) and bovine serum albumin (BSA) were purchased from Behring (King of Prussia, PA) and Sigma-Aldrich (St. Louis, MO), respectively. Recombinant VP1 of Rhinovirus 89 (VP1 89) was expressed as His-tagged protein. ${ }^{18}$ Allergens and fluorescence-labelled BSA were from Phadia Austria GmbH (Part of Thermo Fisher Scientific ImmunoDiagnostics, Vienna, Austria). Detection system controls were: huIgG $_{1}$, huIgG 2 , huIgG ${ }_{3}$, huIgG 4 (Sigma-Aldrich); huIgG, huIgA, huIgM (Jackson ImmunoResearch, West Grove, PA) and huIgE, isolated from a pool of plasma and sera from different patients by anti-IgE affinity chromatography. ${ }^{19}$

Anti-huIgG (Phadia-Thermo Fisher), $\alpha$-huIgG $1, \alpha-$ huIgG $_{2}$ and $\alpha$-huIgA (Becton Dickinson, Franklin Lakes, NJ) and $\alpha$-HSA antibodies (Sigma-Aldrich) were labelled with DyLight 650 (Pierce, Thermo Fisher Scientific, Rockford, IL, USA). $\alpha$-huIgG (Sigma-Aldrich), $\alpha$-huIgG $_{4}, \alpha$-huIgM (Becton Dickinson) and $\alpha$-huIgE (Phadia-Thermo Fisher) were labelled with DyLight 550 (Pierce, Thermo Fisher Scientific).

Cleaning and coating of glass slides was performed as described by Harwanegg et al., ${ }^{20}$ In brief, microscopy glass slides were sonicated in acetone and then in a $1 \%$ Alconox solution (Sigma-Aldrich) to clean the surface. The glass surface was then made reactive for primary amine groups using a silylation procedure, ${ }^{21}$ then the silane layer was heated, cooled and an amine-reactive complex organic polymer was added. $^{20}$ Customized spotting was performed by slow pin mode printing, each spot containing 50-200 fg of microarray component, corresponding to 1-5 attomol (Phadia Austria $\mathrm{GmbH}$ ). For standard spotting, microarray components were used at a concentration of $0.5 \mathrm{mg} \mathrm{ml}^{-1}$ in phosphate buffer pH 8.4 and spotted in triplicates. Optimization of spotting conditions was required for certain antigens and is described 
in the ESI. $\dagger$ Sequential dilutions of antibody controls $(0.125$, $0.062,0.031,0.016,0.008,0.004 \mathrm{mg} \mathrm{ml}^{-1}$ ) were obtained by mixing the antibodies with the corresponding amount of BSA in order to obtain a final spotting concentration of $0.25 \mathrm{mg} \mathrm{ml}^{-1}$ of total protein (component + BSA) in PBS pH 7.2. Two series of triplicates were spotted for gp120, gp41 and 120/15. Correct spotting of the negative control HSA was verified by detection with fluorescence labelled $\alpha$-HSA antibody.

\section{Serum samples}

Sera from 15 African HIV-infected patients $(n=47)$ were from the Asthma, Allergy and Immune Dysfunction Clinic, Harare, Zimbabwe. Fifteen European HIV-positive sera and 15 control sera (i.e. tested HIV-negative in conventional diagnostic tests at the date of microarray analyses) were obtained from the Department of Virology of the Medical University of Vienna. Sequential serum samples were obtained from the 15 African patients on highly active antiretroviral treatment (HAART) during 2009-2011. The HIV status of each of the sera was verified by confirmatory HIV Line-Immuno-Assay (InnoLIA, Innogenetics, Gent, Belgium). Analysis of the anonymized sera was approved by the ethics committee of the Medical University of Vienna (EK592/2010) and was performed according to standardized laboratory work procedures for infectious materials. ${ }^{22,23}$

\section{Microarray-based determination of antibody levels in human serum samples}

To avoid assay-interference by lipid drops, serum samples were centrifuged for $1 \mathrm{~min}$ at $8000 \mathrm{~g}$ and the non-lipidic interphase was diluted in sample diluent (1:50 for detection of $\mathrm{IgG}, \mathrm{IgG}_{1}$, IgA and IgM; $1: 10$ for $\operatorname{IgG}_{2}, \mathrm{IgG}_{3}, \mathrm{IgG}_{4}$; undiluted for IgE measurements). Microarrays were washed by stirring $5 \mathrm{~min}$ in washing buffer (Phadia Austria GmbH). After drying the slides by centrifugation (1000 g, $1 \mathrm{~min}$, room temperature), $30 \mu \mathrm{l}$ sample were applied on each microarray and incubated for 2 hours at gentle rocking at room temperature. Microarrays were then rinsed and washed $5 \mathrm{~min}$ as described above. After centrifugation, they were incubated $30 \mathrm{~min}$ with $30 \mu \mathrm{l}$ of fluorescence-labelled antibodies $\left(1 \mu \mathrm{g} \mathrm{ml}{ }^{-1}\right)$, rocking at room temperature. Microarrays were again rinsed with washing buffer, washed 5 min by stirring in washing buffer and then washed 5 min in distilled water. After drying by centrifugation, the slides were scanned at $635 \mathrm{~nm}$ (DyLight 550-labelled antibodies) or at $532 \mathrm{~nm}$ (DyLight 650-labelled antibodies) using a confocal laser scanner (LuxScan-10K microarray scanner, CapitalBio, Beijing, People's Republic of China). For calibration and determination of background signals, a calibrator serum (i.e. a pool of HIV-positive sera, diluted 1:100) and sample diluent were included in each analysis run. IgG levels to control antigens (i.e., allergens) listed in Table 3 were additionally tested for the calibrator serum by ImmunoCAP. A calibration curve was generated relating fluorescence intensities derived from scanning the microarrays with antibody levels measured by
ImmunoCAP. Due to the semi-quantitative character of antibody levels measured by microarray, results are given in ISAC standardized units (ISU). ${ }^{24}$ The Phadia Microarray Image Analysis software was used to evaluate the measurements, to calculate the mean fluorescence intensities of triplicate analyses and to calibrate the results.

\section{Background signals, intra- and inter-batch variation and data analysis}

Background reactivity of fluorescence-labelled $\alpha$-huIgG towards components spotted on the HIV microarray was determined by testing seven replicates of sample diluent alone. Variation among microarray measurements performed on the same day and on two consecutive days was analysed testing IgG reactivity of 4 and 3 replicates of the calibrator serum, respectively. Microarrays of the same lot were used in both cases. Mean coefficients of variation $(\mathrm{CV}=\mathrm{SD} / \mathrm{mean})$ and signal-to-noise ratios $(\mathrm{SNR}=$ mean/SD) were calculated from ISU for component-specific reactivities. Serum titration experiments were performed testing HIVpositive and control samples at dilutions $1: 10,1: 50,1: 100$, $1: 200$ and $1: 400$. The cut-off for positive reactivity was set at 3 ISU, based on comparison with negative controls.

For data analysis, the background signal of each antigen was subtracted from the measured reactivity. The distribution of the reactivity of the detection antibodies towards spotted antibody controls was analysed with GraphPad Prism (La Jolla, CA, USA). For each HIV-derived component differences between IgG levels of HIV-positive samples and controls were analysed by Mann Whitney $U$ tests; receiver operating characteristic (ROC) curves ( $x$-axes: 1 -specificity; $y$-axes: sensitivity) were generated and the respective area under the curve (AUC) values were calculated (GraphPad Prism). Median antigen-specific IgG levels measured in African and European HIV-positive sera were calculated (GraphPad Prism). Differences between IgG reactivities of the two populations were analysed by Mann Whitney $\mathrm{U}$ tests (IBM SPSS-Statistics, Version 20.0, IBM Corp, Armonk, NY, USA).

\section{Comparison of microarray- and ELISA-based determination of HIV-specific IgG levels}

IgG levels of sera from 15 African HIV-positive, 15 European HIV-positive and 10 control subjects tested with the HIV microarray, were determined also by ELISA. Sera diluted 1:200 in PBS, 0.5\% BSA, 0.05\% v/v Tween 20 (PBST) were tested on plates coated overnight at $4{ }^{\circ} \mathrm{C}$ with $2 \mu \mathrm{g} \mathrm{ml}{ }^{-1}$ of peptides/proteins in $100 \mathrm{mM}$ sodium bicarbonate buffer $\mathrm{pH}$ 9.6, after blocking for $4 \mathrm{~h}$ at room temperature (2\% BSA, PBST). After washing with PBST, bound antibodies were detected by $1 \mathrm{~h}$ incubation with HRP-labelled $\alpha$-huIgG $(1: 5000,0.5 \%$ BSA, PBST). The colour reaction induced with 2,2'-azino-bis(3-ethylbenzothiazoline-6-sulfonicacid)di-ammoniumsalt was measured as optical density $\left(\mathrm{OD}_{405} \mathrm{~nm}-\mathrm{OD}_{490 \mathrm{~nm}}\right)$. Antibody levels measured with the HIV microarray (ISU) were plotted against levels measured by ELISA (OD) for the single peptides/proteins tested and correlation coefficients $\left(R^{2}\right)$ were calculated in Excel. 


\section{Results}

Design of a chip containing a comprehensive set of micro-arrayed peptides and proteins of the HIV-1 clade $\mathrm{C}$ proteome

The HIV chips consist of glass slides containing six microarrays surrounded by a Teflon frame which allow the simultaneous application of six independent samples (Fig. 1a, b). ${ }^{24}$ The Teflon frame was made in oval shape to allow incubation on a rocking plate so that serum samples can better access the areas in the outer parts of the arrays.

Each HIV microarray was designed to contain proteins and peptides from HIV-1 clade $\mathrm{C}$ and control components (i.e. antigens from other sources for which calibration sera were available such as VP1 from human rhinovirus, allergens or antigens which served as positive controls such as purified antibody isotopes, subclass dilutions) (Fig. 1c, Tables 1-3). Among HIV components, two panels of synthetic overlapping peptides from the envelope proteins gp120 and gp41 were included to map linear epitopes of envelope-specific antibodies (Table 1; Fig. 1c, left). Recombinant folded glycosylated envelope proteins were included together with folded structural, functional and accessory proteins to characterize HIV-specific conformation-dependent antibody responses (Table 2, Fig. 1c, left). Additionally, to map linear epitopes of accessory proteins we included peptides derived from VIF, VPR, VPU and REV (Table 1; Fig. 1c, right).

Control components included: i) calibration components for which the amount of IgG antibodies contained in a calibrator serum had been determined by quantitative ImmunoCAP measurements (Table 3); ii) detection system controls, consisting of sequential dilutions of purified human antibody preparations (IgG, IgA, IgM, IgE) and purified monoclonal human IgG subclasses $\left(\operatorname{IgG}_{1-4}\right)$; iii) positive controls (e.g. allergens showing $\operatorname{IgE}, \mathrm{IgG}_{1}, \mathrm{IgG}_{4}, \mathrm{IgG}_{2}$ reactivity, human rhinovirus-derived VP1 showing $\operatorname{IgG}_{1}, \operatorname{IgG}_{3}$, IgA, IgM reactivity with the calibrator serum) and negative controls (HSA, BSA); iv) fluorescence-labelled BSA molecules as "guide-dots" for software-based evaluation (Fig. 1c).

The identity and quality of each of the produced peptides and proteins were examined before spotting. Mass spectrometry analyses showed that the peptides had the correct molecular mass; SDS-PAGE followed by Coomassie Brilliant Blue staining and Western-blot confirmed the identity and purity of the recombinant proteins (i.e., >95\%). Furthermore, circular dichroism measurements showed that each of the recombinant HIV-1 clade $\mathrm{C}$ proteins was folded (Table 2). Thus, the current HIV microarray contained 147 components, of which 72 were derived from 14 different HIV proteins. All a)

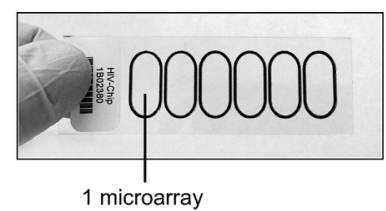

b)

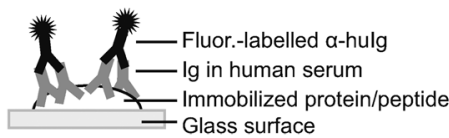

c)

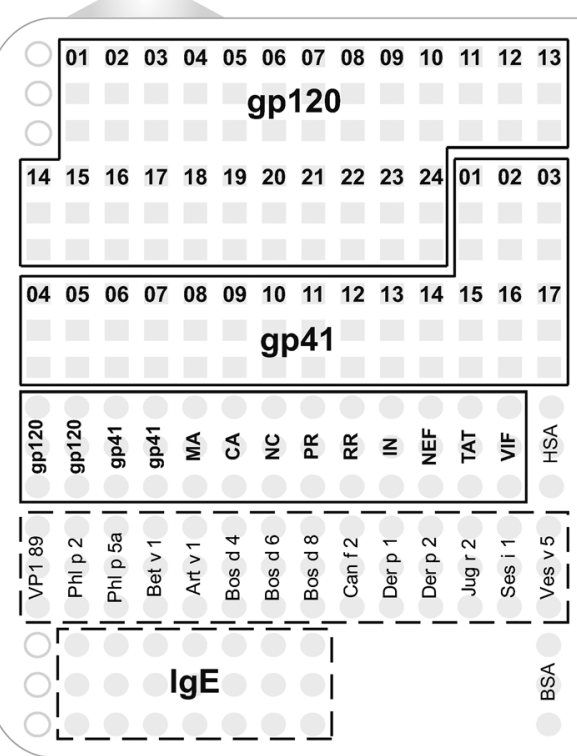

\begin{tabular}{|c|}
\hline Washing (5min) \\
\hline \hline Serum Incubation (2h) \\
\hline \hline Washing (5min) \\
\hline \hline Fluor.-labelled a-hulg (30min) \\
\hline \hline Washing (5min) \\
\hline \hline Scanning (2min) \\
\hline
\end{tabular}
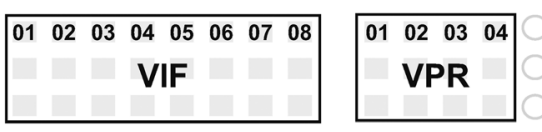

Peptide

Protein

Guide-dot

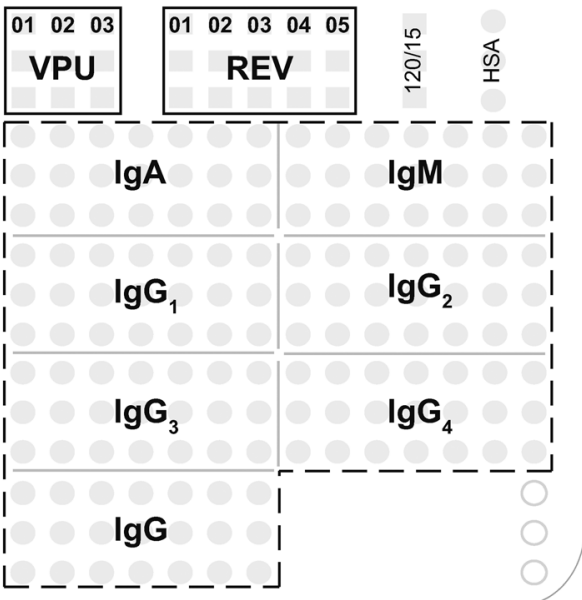

Fig. 1 HIV microarray. (a) Image of the HIV chip containing 6 microarrays. (b) Scheme and flowchart describing the procedure for the detection of HIVspecific antibodies on the microarray. (c) HIV-microarray layout depicting the position of peptide (squares, numbered), protein (filled circles) and guide-dot (open circles) triplicates. Peptides derived from the same HIV proteins (gp120, gp41, VIF, VPR, VPU, REV) and recombinant HIV proteins are boxed. Control proteins (i.e. antibody controls: $\lg \mathrm{A}, \operatorname{lgM}, \lg \mathrm{G}_{1-4}, \operatorname{lgG}$ and $\operatorname{lgE}$ at decreasing concentrations from left to right: 1 st spot $0.250 \mathrm{mg} \mathrm{ml}^{-1}, 2 \mathrm{nd}^{-7}$ th spot 0.125 , $0.062,0.031,0.016,0.008,0.004 \mathrm{mg} \mathrm{ml}^{-1}$ obtained by mixing the antibody with BSA; control antigens: VP1 89 and allergens) are surrounded by broken lines. 
Table 1 HIV-1 peptides spotted on the HIV microarray

\begin{tabular}{|c|c|c|c|c|c|}
\hline Peptide & Amino acid sequence & Position $^{a}$ & $\begin{array}{l}\text { No. of amino } \\
\text { acids }\end{array}$ & $\begin{array}{l}\text { Molecular weight } \\
\text { (dalton) }\end{array}$ & $\begin{array}{l}\text { Calculated isoelectric } \\
\text { point }^{b}\end{array}$ \\
\hline 120/01 & RVRGILRNWPQWWIWGILGFWMIII & $2-28$ & 25 & 3210.9 & 12.3 \\
\hline 120/02 & WMIIICRGEENSWVTVYYGVPVWTE & $24 b-47$ & 25 & 3031.5 & 4.5 \\
\hline 120/03 & PVWTEAKTTLFCASDAKAYEKEVHN & $43-67$ & 25 & 2839.2 & 5.5 \\
\hline 120/04 & KEVHNVWATHACVPTDPSPQELVLE & $63-87$ & 25 & 2800.1 & 5.0 \\
\hline 120/05 & ELVLENVTESFNMWENDMVDQMHED & 83-107 & 25 & 3055.3 & 3.8 \\
\hline 120/06 & QMHEDIIGLWDESLKPCVKLTPLCV & $103-127$ & 25 & 2868.4 & 4.7 \\
\hline 120/07 & TPLCVTLNCNTTSHNNSSPSPMTNC & $123-157$ & 25 & 2636.9 & 6.4 \\
\hline 120/08 & PMTNCSFNATTELRDKTQKVNALFY & 153-177 & 25 & 2893.3 & 8.6 \\
\hline 120/09 & NALFYRSDIVPLEKNSSEYILINCN & 173-197 & 25 & 2916.3 & 4.7 \\
\hline 120/10 & LINCNTSTITQACPKVSFDPIPIHY & $193-217$ & 25 & 2776.2 & 6.7 \\
\hline 120/11 & IPIHYCAPAGYAILKCNNKTFNGTG & $213-237$ & 25 & 2667.1 & 8.8 \\
\hline 120/12 & FNGTGPCSNVSTVQCTHGIKPVVST & $233-257$ & 25 & 2533.9 & 8.1 \\
\hline $120 / 13$ & PVVSTQLLLNGSLAEGEIIIRSENL & $253-277$ & 25 & 2666.1 & 4.2 \\
\hline $120 / 14$ & RSENLTDNAKTIIVHLNKSVAIVCT & $273-297$ & 25 & 2740.2 & 8.2 \\
\hline 120/15 & AIVCTRPNNNTRKSIRIGPGQVFYT & $293-320$ & 25 & 2806.2 & 10.9 \\
\hline $120 / 16$ & QVFYTNEIIGNIRQAHCNISRELWN & $315-339$ & 25 & 3019.4 & 6.7 \\
\hline 120/17 & RELWNNTLEQVKKKLKEHFQNKTIE & $334-360$ & 25 & 3154.6 & 9.4 \\
\hline 120/18 & NKTIEFQPPAGGDLEVTTHSFNCRG & $356-380$ & 25 & 2719.0 & 5.4 \\
\hline 120/19 & FNCRGEFFYCNTSNLFNITASNASD & $376-400$ & 25 & 2836.1 & 4.7 \\
\hline $120 / 20$ & SNASDANNNTITLPCKIKQIINMWQ & $396-428$ & 25 & 2818.2 & 7.9 \\
\hline $120 / 21$ & INMWQEVGRAMYAPPIAGNITCNSS & $424-448$ & 25 & 2724.1 & 6.0 \\
\hline $120 / 22$ & TCNSSITGLLLTRDGGNNNDTGNNN & $444-465 \mathrm{e}$ & 25 & 2565.7 & 4.2 \\
\hline $120 / 23$ & TGNNNDTEIFRPGGGNMKDNWRSEL & $465 a-483$ & 25 & 2823.0 & 4.8 \\
\hline $120 / 24$ & WRSELYKYKVVEIKPLGIAPTKAKRRVVEREKR & $479-511$ & 33 & 4027.8 & 10.4 \\
\hline 41/01 & AVGLGAVLLGFLGTAGSTMGAASIT & $512-536$ & 25 & 2235.6 & 5.6 \\
\hline 41/02 & AASITLTVQARQLLSGIVQQQSNLL & $532-556$ & 25 & 2653.1 & 9.8 \\
\hline 41/03 & QSNLLRAIEAQQHMLQLTVWGIKQL & $552-576$ & 25 & 2919.4 & 8.7 \\
\hline 41/04 & GIKQLQARVLAIERYLKDQQLLGLW & $572-596$ & 25 & 2953.5 & 9.7 \\
\hline 41/05 & LLGLWGCSGKLICTTAVHWNSSWSN & $592-616$ & 25 & 2734.1 & 8.1 \\
\hline 41/06 & SSWSNKSQDYIWGNMTWMQWDREIN & $612-636$ & 25 & 3163.4 & 4.6 \\
\hline 41/07 & DREINNYTDIIYTLLEESQSQQEKN & $632-656$ & 25 & 3044.2 & 4.1 \\
\hline $41 / 08$ & QQEKNEKDLLALDSWNNLWNWFSIT & $652-676$ & 25 & 3093.4 & 4.3 \\
\hline 41/09 & WFSITKWLWYIKIFIMIVGGLIGLR & $672-696$ & 25 & 3054.8 & 10.3 \\
\hline 41/10 & LIGLRIILGVLSIVKRVRQGYSPLS & $692-716$ & 25 & 2751.4 & 11.7 \\
\hline $41 / 11$ & YSPLSFQTLPPNPRGPDRLRGIEEE & $712-736$ & 25 & 2869.2 & 5.1 \\
\hline 41/12 & GIEEEGGEQDKDRSIRLVSGFLALV & $732-756$ & 25 & 2718.0 & 4.4 \\
\hline $41 / 13$ & FLALVWEDLRSLCLFSYHRLRDFIL & $752-776$ & 25 & 3126.7 & 6.7 \\
\hline 41/14 & RDFILIAGRAAELLGRSSLRGLQTG & $772-789$ & 25 & 2671.1 & 11.5 \\
\hline $41 / 15$ & GLQTGWQALKYLGSLVQYWGLELKK & $787 e-809$ & 25 & 2880.4 & 9.4 \\
\hline 41/16 & LELKKSAINLFDTTAIVVAEGTDRL & $805-829$ & 25 & 2718.1 & 4.8 \\
\hline 41/17 & GTDRLIEGLQGIGRAIYNIPRRIRQGFEAALL & $825-856$ & 32 & 3568.1 & 10.6 \\
\hline VIF/01 & MENRWQVLIVWQVDRMRIRTWNSLVKHHMY & $1-30$ & 30 & 3926.6 & 10.8 \\
\hline VIF/02 & KHHMYISKRASRWVYRHHYESRNPRISSEV & $26-55$ & 30 & 3811.3 & 10.5 \\
\hline VIF/03 & ISSEVHIPLGEARLVIKTYWGLHTGERDWQ & $51-80$ & 30 & 3491.9 & 6.0 \\
\hline VIF/04 & ERDWQLGHGVSIEWRLRRYSTQVDPGLADQ & $76-105$ & 30 & 3568.9 & 5.5 \\
\hline VIF/05 & GLADQLIHMHYFDCFADSAIRKAILGQVVS & $101-130$ & 30 & 3319.8 & 6.0 \\
\hline VIF/06 & GQVVSPRCDYQAGHNKVGSLQYLALTALIK & $126-155$ & 30 & 3230.7 & 9.1 \\
\hline VIF/07 & TALIKPKRRKPPLPSVRKLVEDRWNNPQKI & $151-180$ & 30 & 3579.3 & 11.6 \\
\hline VIF/08 & NPQKIRDRRGNHTMNGH & $176-192$ & 17 & 2031.2 & 11.7 \\
\hline REV/01 & AGRSGDSDEALLQAVRIIKILYQSNPPPKP & $2-31$ & 30 & 3234.7 & 8.5 \\
\hline REV/02 & LYQSNPPPKPEGTRQAQRNRRRRWRARQRQ & $22-51$ & 30 & 3788.2 & 12.3 \\
\hline REV/03 & RRRWRARQRQIHSVSERILSTCLGRPAEPV & $42-71$ & 30 & 3615.1 & 12.0 \\
\hline REV/04 & TCLGRPAEPVPLQLPPIERLHIDCRESSGT & $62-91$ & 30 & 3285.7 & 5.5 \\
\hline REV/05 & HIDCRESSGTSGTQQSQGTTDRVASP & $82-107$ & 26 & 2705.8 & 5.4 \\
\hline VPR/01 & EQPPEDQGPQREPYNEWALEILEELKQEAV & $2-31$ & 30 & 3565.8 & 3.9 \\
\hline VPR/02 & ILEELKQEAVRHFPRPWLHNLGQYIYATYG & $22-51$ & 30 & 3643.1 & 6.9 \\
\hline VPR/03 & LGQYIYATYGDTWTGVEALLRILQQLLFIH & $42-71$ & 30 & 3497.0 & 5.3 \\
\hline VPR/04 & RILQQLLFIHFRIGCQHSRIGILRQRRARNGASRS & $62-96$ & 35 & 4158.9 & 12.5 \\
\hline VPU/01 & SFLYASVDYRLGVGALIIAL & $2-16$ & 20 & 2141.5 & 5.5 \\
\hline VPU/02 & EYRKLLRQRKINKLIDRIRDREEDSGNESE & $29-58$ & 30 & 3760.1 & 8.5 \\
\hline VPU/03 & REEDSGNESEGDIEELATMVDMGHLRLLDDNNL & $49-82$ & 33 & 3717.9 & 3.9 \\
\hline
\end{tabular}

${ }^{a}$ Position of the peptides in HIV-1 clade C proteins, numbered according to the HXB2 numbering scheme (www.hiv.lanl.gov). ${ }^{b}$ Based on the amino acid sequence, calculated with ProtParam, Expasy. 
Table 2 HIV-1 proteins spotted on the HIV microarray

\begin{tabular}{|c|c|c|c|c|c|}
\hline Proteins & $\begin{array}{l}\text { Calculated molecular } \\
\text { weight }^{a}(\mathrm{kDa})\end{array}$ & $\begin{array}{l}\text { Calculated } \\
\text { isoelectric point }^{a}\end{array}$ & $\begin{array}{l}\text { Secondary structure } \\
\text { determined by CD }\end{array}$ & Expression system & Final solvent \\
\hline gp120 & 54.8 & 8.2 & $\alpha, \beta$ & Human cells & PBS, 5\% trehalose, 5\% mannitol pH 7.4 \\
\hline gp41 & 18.9 & 6.8 & $\beta(68 \%), \alpha(11 \%)$ & Human cells & $10 \mathrm{mM} \mathrm{NaH}{ }_{2} \mathrm{PO}_{4}, \mathrm{pH} 4.7$ \\
\hline MA & 15.5 & 9.1 & $\alpha(63 \%), \beta(10 \%)$ & E. coli & $\begin{array}{l}50 \mathrm{mM} \text { Tris, } 200 \mathrm{mM} \mathrm{NaCl}, \\
1 \mathrm{mM} \beta \text {-met, } 20 \% \text { glycerol, pH } 5.3\end{array}$ \\
\hline CA & 26.5 & 6.6 & $\alpha(57 \%), \beta(12 \%)$ & E. coli & $\begin{array}{l}10 \mathrm{mM} \text { Na-phosphate, } 150 \mathrm{mM} \mathrm{NaCl} \text {, } \\
10 \% \text { sucrose, pH } 5.0\end{array}$ \\
\hline NC & 7.2 & 10.2 & $\beta(34 \%), \alpha(5 \%)$ & E. coli & $\begin{array}{l}50 \mathrm{mM} \text { Na-phosphate, } 50 \mathrm{mM} \mathrm{NaCl} \text {, } \\
1 \mathrm{mM} \beta \text {-met, pH } 5.5\end{array}$ \\
\hline PR & 24.6 & 6.2 & $\beta(27 \%), \alpha(14 \%)$ & E. coli & $10 \mathrm{mM}$ Na-phosphate, $\mathrm{pH} 4.7$ \\
\hline $\mathbf{R R}$ & 12.2 & 9.0 & $\beta(29 \%), \alpha(12 \%)$ & E. coli & $10 \mathrm{mM}$ Na-phosphate, $\mathrm{pH} 4.7$ \\
\hline IN & 23.7 & 10.5 & $\beta(32 \%), \alpha(12 \%)$ & E. coli & $10 \mathrm{mM}$ Na-phosphate, $\mathrm{pH} 4.7$ \\
\hline NEF & 11.7 & 8.7 & $\beta(42 \%), \alpha(6 \%)$ & E. coli & $\begin{array}{l}20 \mathrm{mM} \text { Tris, } 0.5 \mathrm{M} \mathrm{NaCl}, \\
15 \mathrm{mM} \beta \text {-met, } \mathrm{pH} 7.4\end{array}$ \\
\hline TAT & 65.1 & 6.8 & $\beta(28 \%), \alpha(17 \%)$ & E. coli & $\mathrm{H}_{2} \mathrm{O}$ \\
\hline VIF & 33.2 & 7.4 & $\beta(25 \%), \alpha(19 \%)$ & E. coli & $\begin{array}{l}10 \mathrm{mM} \text { Na-phosphate, } 150 \mathrm{mM} \mathrm{NaCl} \text {, } \\
20 \% \text { glycerol, pH } 6.0\end{array}$ \\
\hline
\end{tabular}

${ }^{a}$ Based on the amino acid sequence, calculated with ProtParam, Expasy. Abbreviations: kDa, kilo Dalton; CD, circular dichroism; $\alpha$, alphahelical structure, $\beta$, beta-sheet structure; E. coli, Escherichia coli; $\beta$-met, $\beta$-mercaptoethanol; Na-phosphate, sodium phosphate.

Table 3 Allergens spotted on the HIV microarray

\begin{tabular}{llll}
\hline $\begin{array}{l}\text { Microarray } \\
\text { component }\end{array}$ & Allergen source & & Recombinant/natural \\
\hline Phl p 2 & Phleum pratense & Timothy & $\mathrm{R}$ \\
Phl p 5a & Phleum pratense & Timothy & $\mathrm{R}$ \\
Bet v 1 & Betula verrucosa & Birch & $\mathrm{N}$ \\
Art v 1 & Artemisia vulgaris & Mugwort & $\mathrm{N}$ \\
Bos d 4 & Bos domesticus & Cattle & $\mathrm{N}$ \\
Bos d 6 & Bos domesticus & Cattle & $\mathrm{N}$ \\
Bos d 8 & Bos domesticus & Cattle & $\mathrm{N}$ \\
Can f 2 & Canis familiaris & Dog & $\mathrm{R}$ \\
Der p 1 & Dermatophagoides & House & $\mathrm{N}$ \\
& pteronyssinus & dust mite & \\
Der p 2 & Dermatophagoides & House & $\mathrm{R}$ \\
& pteronyssinus & dust mite & \\
Jug r 2 & Juglans regia & Walnut & $\mathrm{N}$ \\
Ses i 1 & Sesamum indicum & Sesame & $\mathrm{N}$ \\
Ves v 5 & Vespula vulgaris & Wasp & $\mathrm{R}$
\end{tabular}

components were spotted in triplicates in order to obtain three independent determinations in each experiment (Fig. 1c).

The HIV microarray allows sensitive and specific detection of antibodies towards a comprehensive set of proteins and peptides with minute serum volumes and short assay duration

Antibody detection on the chip involves a washing step followed by application of the serum sample, washing, detection of bound antibodies with fluorescence-labelled antibody conjugates, washing and scanning requiring less than 3 hours (Fig. 1b).

Fig. 2 exemplifies the specificity of the HIV microarray. A sample volume of $30 \mu \mathrm{l}$ was sufficient to detect specific antibody responses against each of the micro-arrayed components. The following serum volumes were needed for detection of the antibody classes/subclasses: IgG (dilution 1:50;0.6 $\mu \mathrm{l}$ ), $\mathrm{IgG}_{1}$ (1:50;0.6 $\mu \mathrm{l}), \operatorname{IgG}_{2}(1: 10 ; 3 \mu \mathrm{l}), \operatorname{IgG}_{3}(1: 10 ; 3 \mu \mathrm{l}), \operatorname{IgG}_{4}(1: 10 ; 3 \mu \mathrm{l})$ IgA $(1: 50 ; 0.6 \mu \mathrm{l}), \operatorname{IgM}(1: 50 ; 0.6 \mu \mathrm{l}), \operatorname{IgE}$ (undiluted; $30 \mu \mathrm{l})$.
Thus, less than $50 \mu$ l of serum allowed determining the specificities of all antibody classes and subclasses to 72 HIV derived proteins and peptides in triplicate analyses.

On scan-images the bound antibodies could be clearly identified as dots of varying intensities and HIV-specific profiles could be used to discriminate HIV-positive from control samples (Fig. 2a, upper and mid panels). Tests performed with sample diluent alone showed specific binding of the IgG detection system towards the spotted antibody controls (IgG, IgG I-4 $_{1}$, IgE-containing preparation) but no nonspecific binding towards any of the other components (Fig. 2a, lower panel). To relate scanned fluorescence levels to amounts of antibody present in serum samples, we determined specific IgG levels of a calibrator serum with the HIV microarray and with quantitative ImmunoCAP (Fig. 3a). The results obtained were used to generate calibration curves and to convert fluorescence levels into ISAC standardized units (ISU). When the calibration curve could be approximated to a linear function, the amount of IgG $(\mu \mathrm{g})$ per $\mathrm{ml}$ of serum could be calculated with the formula $[\mu \mathrm{g}$ IgG per $\mathrm{ml}=$ ISU $\times$ serum dilution factor/1000]: this was observed for values up to $6 \mathrm{ISU}$, which corresponds to $0.3 \mu \mathrm{g}$ IgG per $\mathrm{ml}$ of serum (Fig. 3a).

Intra- and inter-assay replicates of calibrator serum were measured with high reproducibility, as characterized by mean coefficients of variation (CV) $<1$ ISU (i.e., 0.36 and 0.38 ) and signal to noise ratios (SNR) $>1$ ISU (i.e., 8.3 and 5.5). Intraand inter-assay variation were even lower when analysed for IgG levels greater than 35 ISU $(\mathrm{CV}=\mathbf{0 . 1 5}, \mathrm{SNR}=12.4$ and $\mathrm{CV}=$ 0.13, $\mathrm{SNR}=33.6$, respectively).

Background reactivity was measured by incubating arrays with sample diluent alone $(n=7)$. The signals ranged between 0.0 and 0.14 ISU, confirming the absence of nonspecific binding of the detection system. Assessment of the reactivity of anti-huIgG detection antibodies towards spotted antibody controls of different isotype and IgG subclasses 

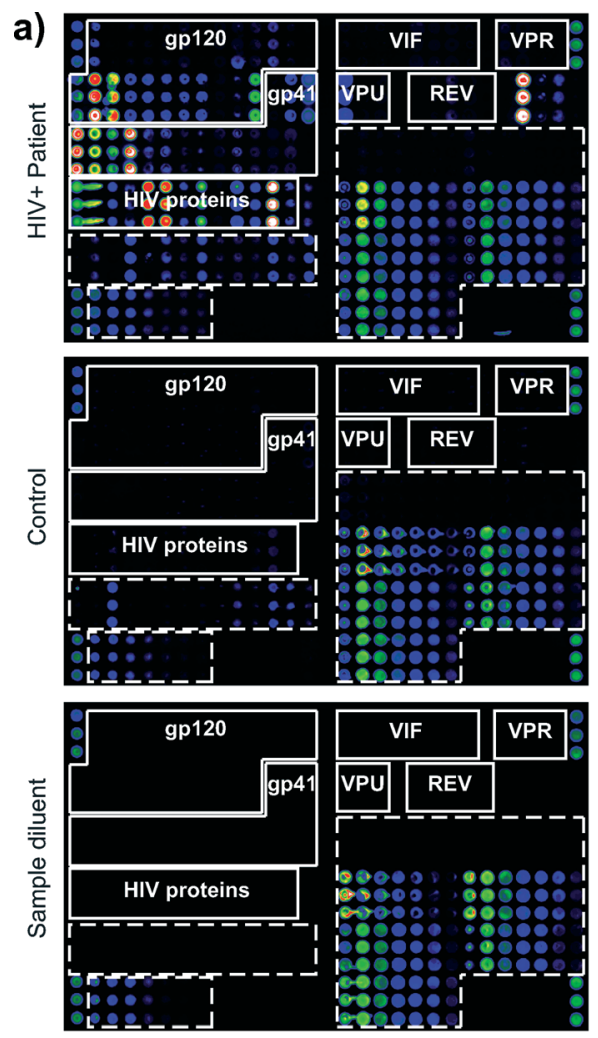
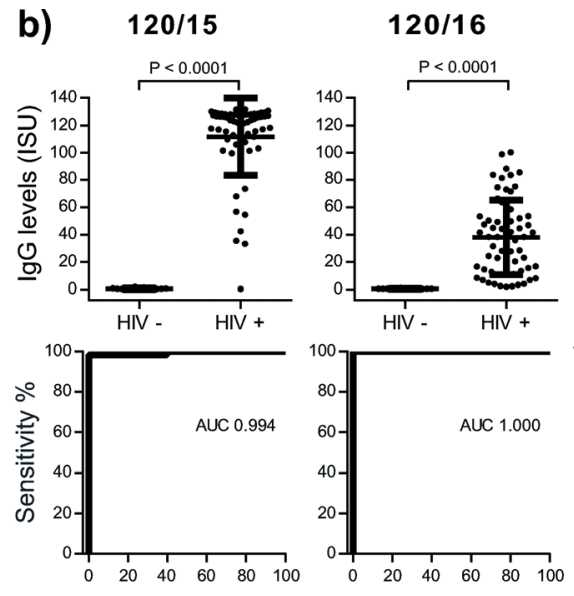

$100 \%$ - Specificity \%
$41 / 04$
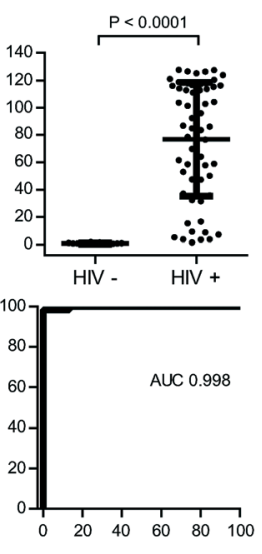

gp120
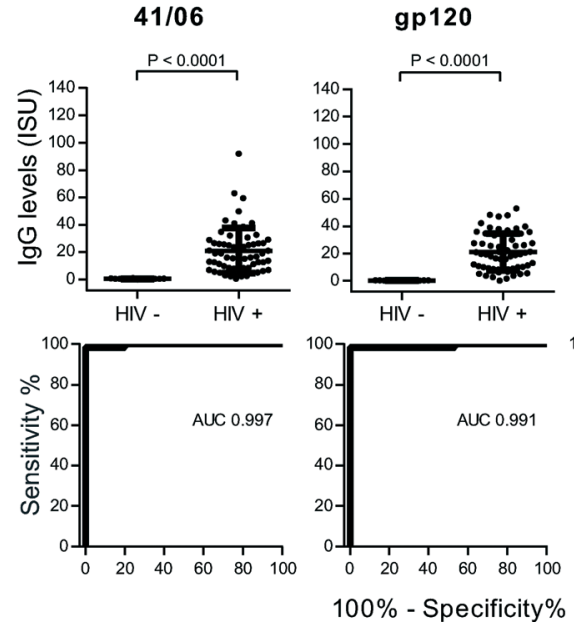

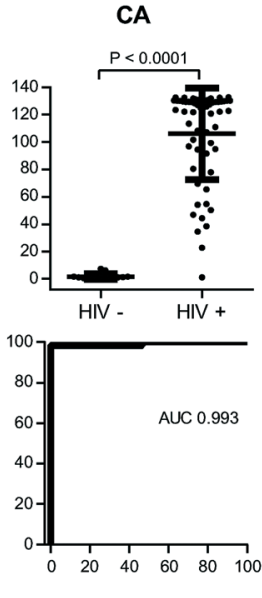

Fig. 2 (a) Scan images obtained from a microarray tested for IgG reactivity with serum from a HIV-positive subject (upper panel), a control serum sample (middle panel) or sample diluent (lower panel). IgG-reactive vertical antigen triplicates are visualized with fluorescent-labelled antibodies. Increasing fluorescence intensities from blue to red/white correspond to the amount of bound IgG. The layout of spotted antigens is shown in Fig. 1c. (b) IgG levels of HIV-infected patients and controls are shown together with ROC curves for antigens with AUC $>0.99$. Median IgG levels (horizontal lines), $P$-values of test significance and AUC values are indicated in each figure part.

showed specific and concentration-dependent binding of the fluorescence-labelled anti-huIgG antibody (Fig. 3b).

We then performed serum titration experiments with HIV-positive sera at dilutions of $1: 10,1: 50,1: 100,1: 200$, $1: 400$ that identified $1: 50$ as a suitable serum dilution (Fig. 3c). Thus, $0.6 \mu \mathrm{l}$ of serum were sufficient for the determination of IgG reactivities towards the panel of spotted components.

Next we tested 62 HIV-positive sera and 15 control sera, replicates of the calibrator serum $(n=2)$ and sample diluent $(n=2)$. Ranges and median IgG levels for each of the HIV components are shown in Table S1 $\dagger$ IgG levels to micro-arrayed HIV-derived peptides and proteins were significantly higher in HIV-positive samples than in controls for all components, except 120/01, 120/07 and VIF/08 (Table S1†). To estimate the use of microarrays for diagnostic purposes, we analysed sensitivity and specificity for each HIV-derived component with ROC curves (Table S1†). The highest areas under the curve (AUC) were measured for: 120/15, 120/16, 41/04, 41/05, 41/06, gp120 and CA (AUC > 0.99, Fig. 2b) and followed by 120/09, 120/17,
120/24, 41/07, 41/16, MA and IN (0.98 < AUC $\leq$ 0.99). Thus, determination of IgG levels towards these micro-arrayed HIV-derived components may be useful for diagnosis.

\section{Comparison of the HIV microarray with ELISA}

For HIV components that had high median IgG levels and AUC > 0.98 we compared IgG levels determined by microarray with results obtained by ELISA measurements (Fig. 4). A positive correlation was found between the two assays for peptides 120/15, 120/24, 41/04, 41/05 and proteins gp120, MA and CA. Interestingly, IgG levels against two peptides 120/16 and 41/06 were detected only when immobilized on the microarray but not by ELISA and were specific for HIV-infected patients. The lack of IgG binding to the peptides by ELISA may be due to the fact that the peptides $120 / 16$ and 41/06 did not bind to the ELISA plate.

IgG levels against gp120 were lower when detected on the microarray than by ELISA and were lower than envelope 
a)

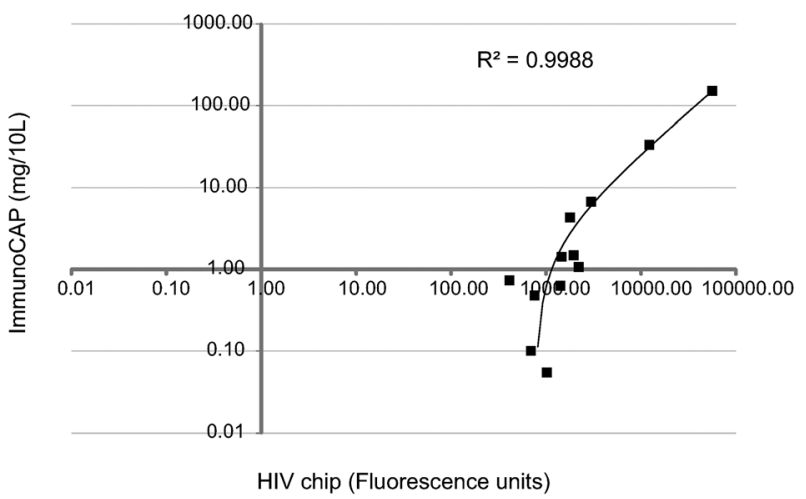

b)
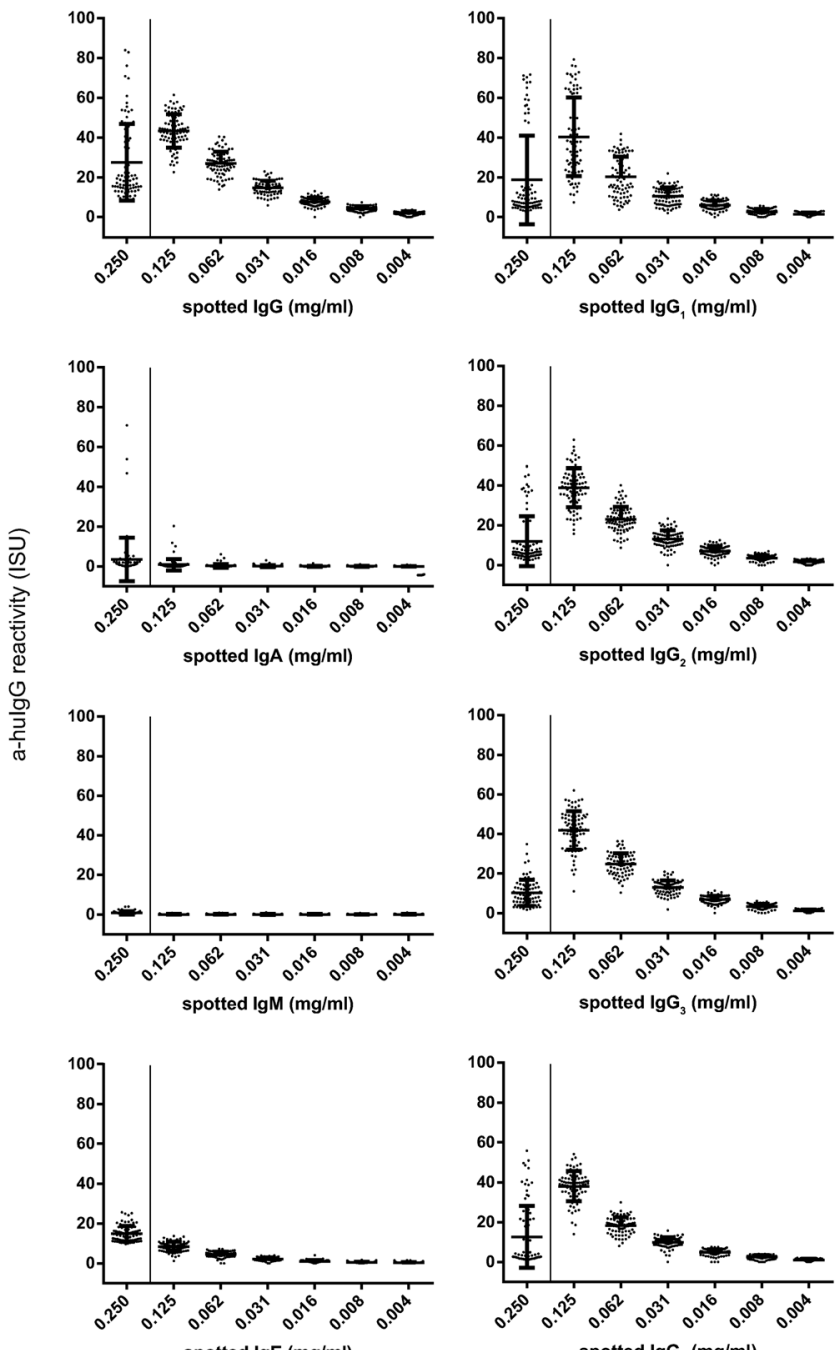

spotted lgE (mg/ml)
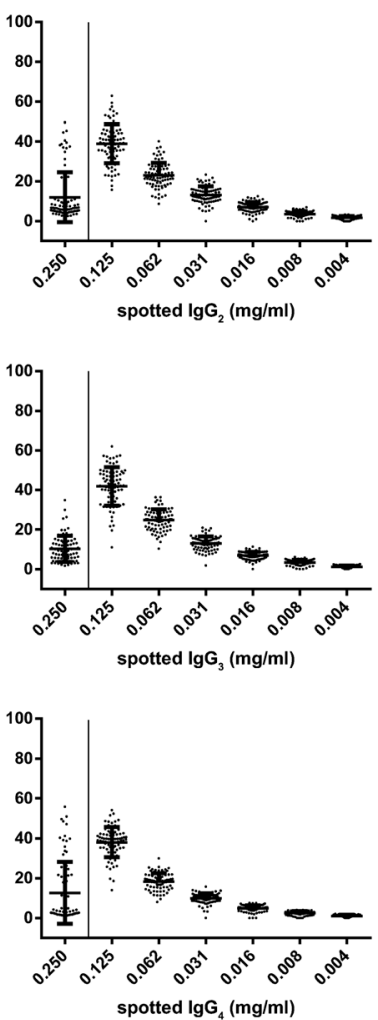

c)

\begin{tabular}{|c|c|c|c|c|c|}
\hline \multirow{2}{*}{ Component } & \multicolumn{5}{|c|}{$\mathrm{HIV}+\# 8 \mathrm{C}$} \\
\hline & 1:10 & 1:50 & $1: 100$ & $1: 200$ & $1: 400$ \\
\hline $120 / 01$ & 4.7 & 8.7 & 6.5 & 0.6 & 1.1 \\
\hline 120/02 & 1.8 & 0.6 & 0.2 & 0.2 & 0.2 \\
\hline $120 / 03$ & 1.8 & 1.2 & 0.7 & 0.3 & 0.3 \\
\hline $120 / 04$ & 8.3 & 2.2 & 0.9 & 0.8 & 0.8 \\
\hline 120/05 & 1.2 & 1.4 & 0.3 & 0.2 & 0.2 \\
\hline $120 / 06$ & 8.0 & 2.8 & 1.3 & 1.0 & 0.9 \\
\hline $120 / 07$ & 1.0 & 0.4 & 0.1 & 0.2 & 0.1 \\
\hline 120/08 & 3.3 & 1.9 & 1.1 & 0.8 & 1.4 \\
\hline $120 / 09$ & 10.5 & 3.7 & 1.5 & 1.1 & 1.0 \\
\hline $120 / 10$ & 5.8 & 2.7 & 1.5 & 1.1 & 1.7 \\
\hline $120 / 11$ & 7.2 & 3.9 & 2.4 & 1.7 & 3.0 \\
\hline 120/12 & 2.7 & 2.6 & 0.3 & 1.0 & 1.5 \\
\hline 120/13 & 1.0 & 0.3 & 0.2 & 0.2 & 0.2 \\
\hline $120 / 14$ & 12.7 & 33.0 & 26.7 & 19.2 & 19.5 \\
\hline $120 / 15$ & 188.3 & 162.9 & 189.8 & 218.3 & 198.4 \\
\hline $120 / 16$ & 151.2 & 124.0 & 81.7 & 64.4 & 58.6 \\
\hline $120 / 17$ & 41.3 & 21.6 & 4.9 & 30.5 & 15.8 \\
\hline 120/18 & 26.3 & 11.9 & 12.5 & 6.9 & 15.3 \\
\hline $120 / 19$ & 38.3 & 10.0 & 11.0 & 21.6 & 14.5 \\
\hline $120 / 20$ & 37.1 & 9.0 & 6.2 & 4.0 & 5.8 \\
\hline $120 / 21$ & 14.9 & 10.6 & 3.1 & 10.9 & 10.1 \\
\hline $120 / 22$ & 1.7 & 0.6 & 0.5 & 0.3 & 0.8 \\
\hline $120 / 23$ & 9.1 & 5.1 & 2.7 & 4.7 & 4.3 \\
\hline $120 / 24$ & 186.2 & 90.5 & 46.2 & 33.0 & 21.6 \\
\hline $41 / 01$ & 9.1 & 0.7 & 0.5 & 1.1 & 0.9 \\
\hline $41 / 02$ & 32.2 & 9.4 & 4.9 & 11.8 & 18.5 \\
\hline $41 / 03$ & 43.7 & 14.4 & 5.1 & 3.5 & 1.4 \\
\hline $41 / 04$ & 189.7 & 146.8 & 127.2 & 126.1 & 82.4 \\
\hline $41 / 05$ & 100.5 & 63.0 & 41.4 & 32.9 & 18.8 \\
\hline $41 / 06$ & 16.4 & 34.9 & 16.9 & 11.2 & 6.0 \\
\hline $41 / 07$ & 171.5 & 172.0 & 147.6 & 93.5 & 52.9 \\
\hline $41 / 08$ & 8.4 & 3.3 & 1.3 & 4.9 & 6.2 \\
\hline $41 / 09$ & 16.1 & 4.0 & 1.8 & 3.2 & 2.0 \\
\hline $41 / 10$ & 10.9 & 2.6 & 1.6 & 1.5 & 1.4 \\
\hline $41 / 11$ & 2.0 & 2.1 & 1.1 & 1.2 & 0.7 \\
\hline $41 / 12$ & 3.2 & 1.5 & 2.3 & 1.7 & 1.0 \\
\hline $41 / 13$ & 5.9 & 6.9 & 1.6 & 1.7 & 1.3 \\
\hline $41 / 14$ & 4.3 & 1.9 & 1.1 & 0.5 & 0.3 \\
\hline $41 / 15$ & 2.5 & 1.2 & 0.6 & 0.3 & 0.1 \\
\hline $41 / 16$ & 7.7 & 2.4 & 2.5 & 1.8 & 1.0 \\
\hline $41 / 17$ & 1.9 & 0.6 & 0.2 & 0.2 & 0.1 \\
\hline gp120 & 49.8 & 37.8 & 41.3 & 27.1 & 55.7 \\
\hline gp41 & 12.8 & 108.3 & 83.9 & 5.5 & 5.1 \\
\hline MA & 135.2 & 75.7 & 79.1 & 28.6 & 22.7 \\
\hline CA & 213.2 & 141.4 & 95.3 & 57.7 & 37.1 \\
\hline NC & 14.8 & 6.5 & 3.5 & 2.3 & 2.7 \\
\hline PR & 80.7 & 34.0 & 22.7 & 19.5 & 16.9 \\
\hline RR & 1.1 & 0.5 & 0.3 & 0.2 & 0.2 \\
\hline IN & 12.7 & 3.5 & 3.7 & 1.3 & 0.6 \\
\hline NEF & 17.0 & 8.8 & 5.0 & 2.5 & 2.9 \\
\hline TAT & 200.0 & 169.9 & 135.5 & 102.5 & 79.0 \\
\hline VIF & 7.4 & 2.5 & 0.3 & 1.3 & 1.0 \\
\hline VIF/01 & 3.7 & 2.0 & 1.2 & 0.9 & 0.6 \\
\hline VIF/02 & 2.9 & 1.2 & 0.7 & 0.7 & 0.5 \\
\hline VIF/03 & 2.4 & 1.2 & 0.5 & 0.3 & 0.3 \\
\hline VIF/04 & 1.3 & 0.4 & 0.2 & 0.1 & 0.1 \\
\hline VIF/05 & 9.5 & 2.2 & 0.9 & 0.6 & 0.4 \\
\hline VIF/06 & 2.7 & 0.8 & 0.5 & 0.4 & 0.6 \\
\hline VIF/07 & 3.1 & 1.4 & 0.5 & 0.3 & 0.2 \\
\hline VIF/08 & 1.8 & 0.6 & 0.3 & 0.2 & 0.1 \\
\hline VPR/01 & 4.6 & 2.6 & 0.4 & 0.7 & 0.4 \\
\hline VPR/02 & 8.9 & 2.8 & 0.9 & 0.8 & 0.5 \\
\hline VPR/03 & 1.0 & 0.2 & 0.0 & 0.1 & 0.0 \\
\hline VPR/04 & 1.2 & 0.4 & 0.1 & 0.2 & 0.2 \\
\hline VPU C1 & 33.2 & 13.7 & 6.5 & 4.6 & 2.9 \\
\hline VPU C2 & 2.6 & 0.5 & 0.2 & 0.2 & 0.3 \\
\hline VPUET & 1.5 & 0.7 & 1.1 & 1.1 & 2.0 \\
\hline REV/01 & 1.4 & 0.5 & 0.4 & 0.3 & 0.3 \\
\hline REV/02 & 1.3 & 0.5 & 0.4 & 0.3 & 0.8 \\
\hline REV/03 & 7.0 & 3.5 & 1.8 & 1.1 & 0.7 \\
\hline REV/04 & 4.0 & 1.4 & 1.0 & 0.9 & 1.3 \\
\hline REV/05 & 1.0 & 0.4 & 0.3 & 0.4 & 0.6 \\
\hline HSA & 2.9 & 2.4 & 1.5 & 1.2 & 1.1 \\
\hline
\end{tabular}

Fig. 3 (a) Fluorescence levels determined by microarray ( $x$-axes) for calibration components (i.e., allergens listed in Table 3) are shown with corresponding IgG levels measured by ImmunoCAP ( $y$-axes). (b) Reactivity of anti-human IgG detection antibody with spotted preparations of human antibody isotypes (IgG, IgA, IgM, IgE) and human monoclonal IgG subclasses (IgG $\mathrm{I}_{-4}$ ) measured by microarray (expressed as ISAC standardized units, ISU). Reactivity is shown for antibody controls spotted at $0.25 \mathrm{mg} \mathrm{ml}^{-1}$ ( $x$-axes, left) as well as mixed with BSA at decreasing concentrations $\left(0.125,0.062,0.031,0.016,0.008,0.004 \mathrm{mg} \mathrm{ml}^{-1}, x\right.$-axes, right). (c) IgG levels determined by microarray (ISU) towards spotted components in serum titration analyses of an HIV-infected sample (\#8c) at sequential serum dilutions (1:10-1:400). Positive reactivity is shown in grey. 

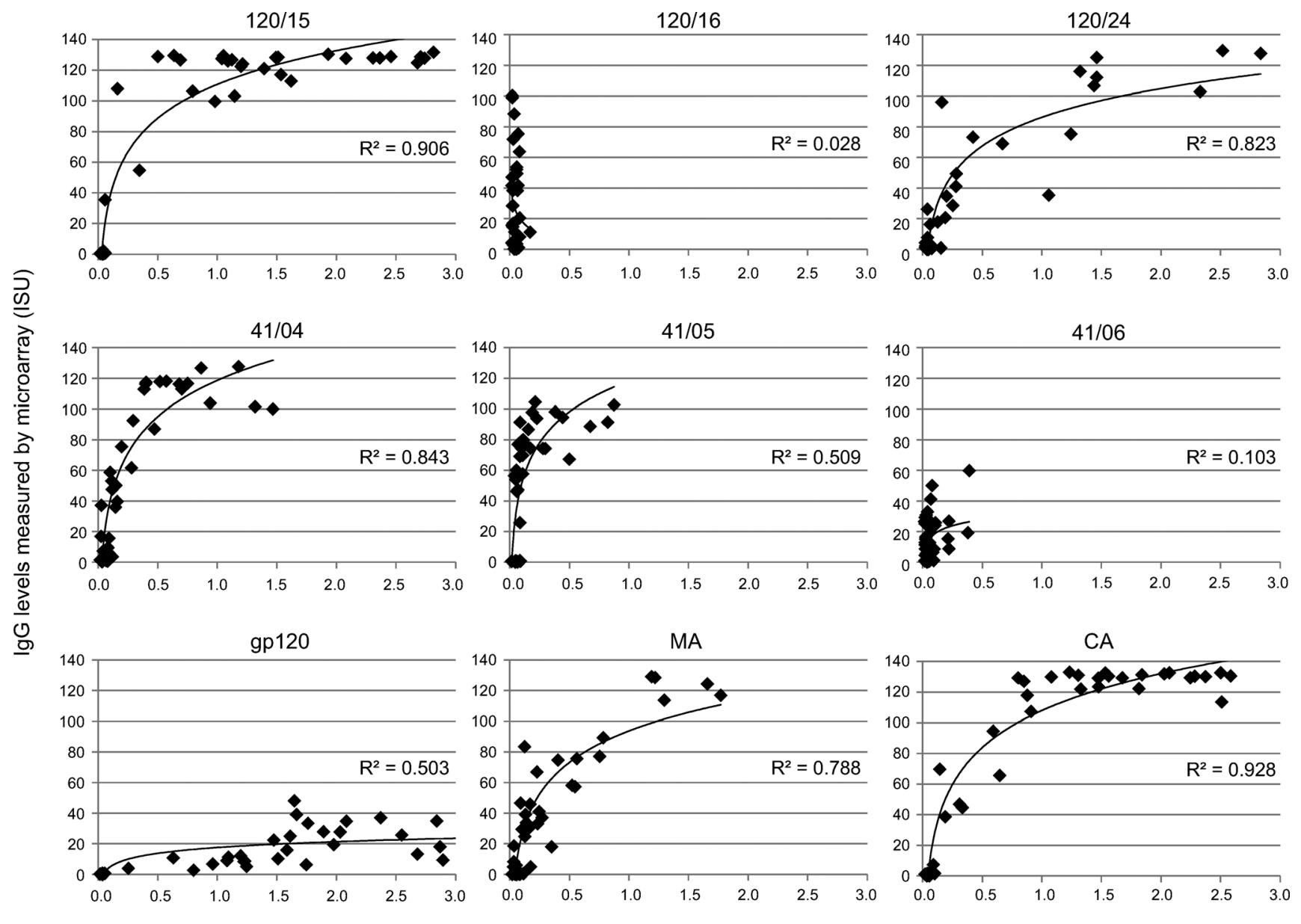

IgG levels measured by ELISA (OD)

Fig. 4 Comparison of microarray- and ELISA-based determination of HIV-specific IgG. IgG levels measured by microarray, expressed in ISAC standardized units (ISU, $y$-axes) are plotted against IgG levels determined by ELISA as optical densities (OD, $x$-axes) for peptides/proteins with an AUC (area under the curve) $>0.98$ and high median IgG levels.

peptide-specific responses (Fig. 5). This could be due to the fact that proteins and peptides were immobilized at the same concentration. Thus, a smaller number of molecules was spotted in case of high molecular weight proteins such as the proteins gp120 and gp41, in comparison to low molecular weight peptides. Another possible explanation for the low reactivity compared to ELISA could be a lower binding of gp120 and gp41 to the chip surface. Finally, it is possible that the carbohydrate moieties on gp120 and gp 41 blocked reactivity of peptide-specific antibodies or that these peptides represent cryptic epitopes which were not fully accessible on the intact glycosylated proteins used by us.

The HIV microarray allows mapping of IgG reactivity profiles towards a comprehensive set of HIV-proteins and peptides representing the proteome of given strains

Next, we tested the antibody recognition profiles of HIVinfected patients from an African region where clade $\mathrm{C}$ is predominant (i.e., Zimbabwe) $)^{25}$ and compared it with that of patients from a region were HIV-1 clade C is not endemic (i.e., Europe) ${ }^{26}$ We found that clade $\mathrm{C}$-derived envelopederived peptides (Fig. 5a) and HIV proteins (Fig. 5b) were recognized by African and also European HIV-infected patients. The highest median IgG levels were observed in both populations towards gp120-derived peptides 120/15, 120/16 and 120/24, gp41-derived peptides 41/04, 41/05, 41/06 and gp120, MA, CA and PR proteins (Fig. 5a, b). Strong antibody reactivity was observed in both populations also towards 41/07 and 41/17 (Fig. 5a). Control subjects without HIV infections showed no binding to the micro-arrayed components except towards peptide 120/01, which covers the signal peptide of the protein, and occasional reactivity was found in single sera towards peptides 120/04, 120/10, 120/18, $41 / 03$ and 41/10. IgG levels towards peptides derived from HIV accessory proteins were low in both African and European HIV-infected populations (Fig. S1a†). Common peptide epitopes recognized by African and European patients were VPU/01, VPU/02 and REV/03. Peptides VIF/04, VIF/05, VIF/07 showed IgG reactivity with single sera from control subjects. IgG responses towards control components to which most subjects are exposed (i.e., allergens and VP1) were found in 
a)

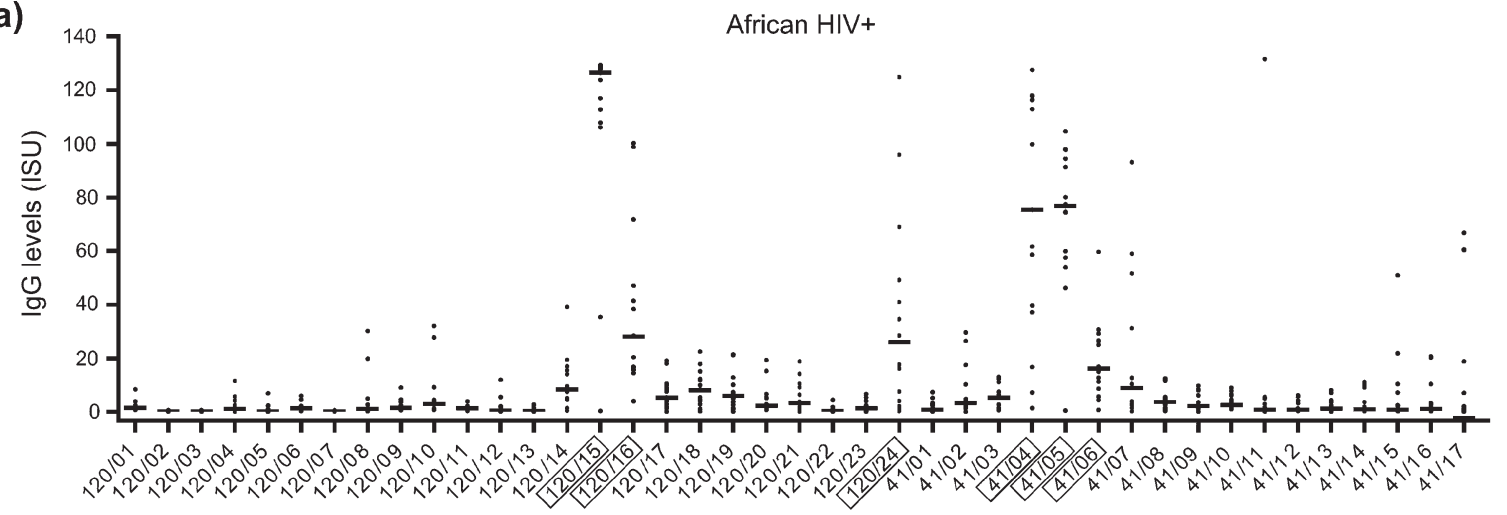

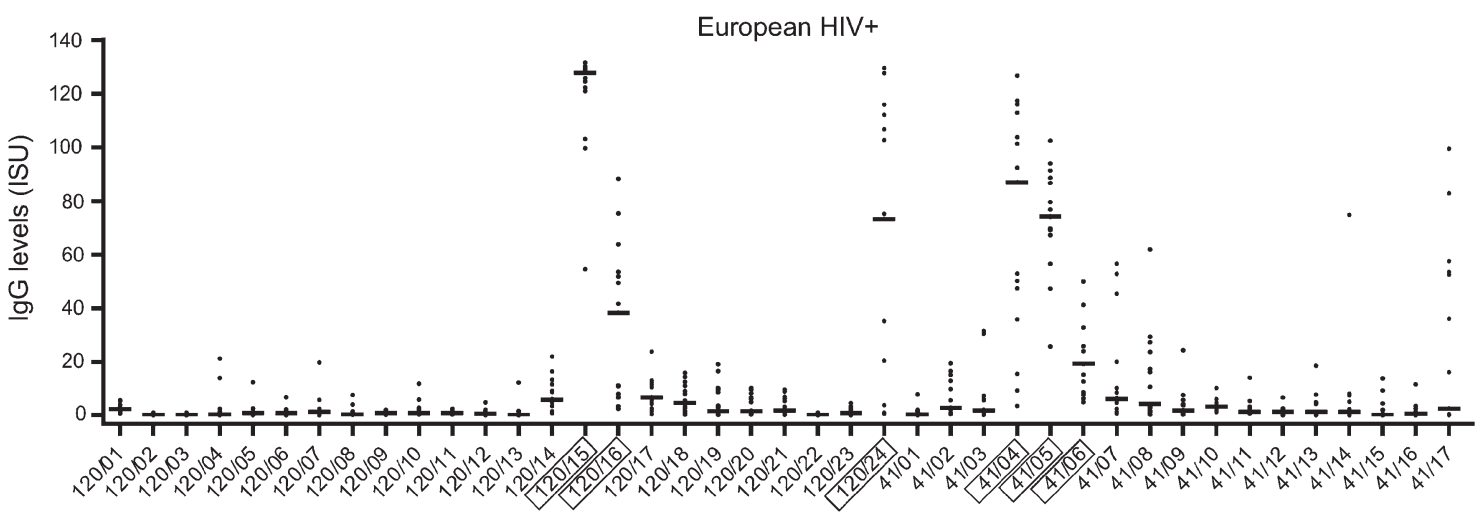
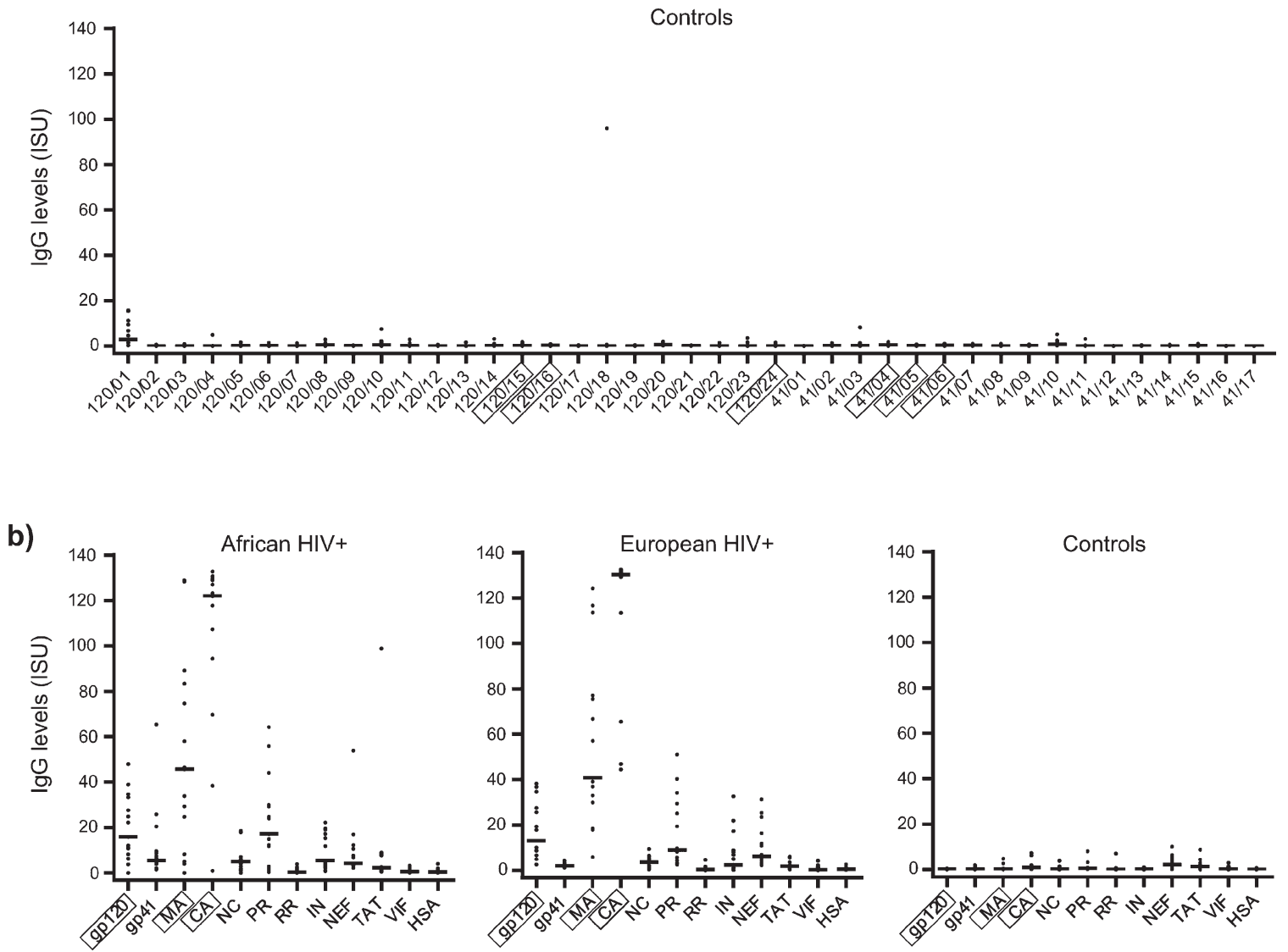

Fig. 5 Microarray-based mapping of HIV-specific IgG responses in African and European HIV-infected individuals and controls. IgG levels ( $y$-axes, ISAC standardized units, ISU) to micro-arrayed gp120- and gp41-derived peptides (a) as well as to HIV proteins and HSA (b) are shown for African HIV-positive patients $(n=15)$, European HIV-positive patients $(n=15)$ and controls $(n=15)$. Median IgG levels are indicated for each peptide/protein (horizontal lines). Peptides/proteins with an AUC (area under the curve) $>0.98$ and high median IgG levels are boxed. 
HIV-infected patients as well as in control individuals (Fig. S1b $\dagger$ ).

The HIV microarray can be used to measure HIV-specific antibody responses for various isotypes and IgG subclasses

We also evaluated if the HIV microarray could be used for detection of HIV-specific IgG subclasses (i.e. IgG IgG $_{2}, \operatorname{IgG}_{3}$ and $\mathrm{IgG}_{4}$ ) and for detection of specific IgA, IgM and IgE responses in sera from HIV-infected patients. Fig. 6 shows examples of scan-images of microarray-based antibody determinations of an HIV-positive and a control serum. In the HIVpositive serum sample shown, specific IgG and IgG $_{1}$ antibodies were found towards many of the HIV-derived components, whereas specific $\operatorname{IgG}_{3}$, IgA and IgM reactivity occurred only towards certain HIV-derived and allergen components (Fig. 6). In serum samples from other HIV-infected patients we detected also $\mathrm{IgG}_{2}$ and $\mathrm{IgG}_{4}$ subclass responses towards HIV antigens/peptides, whereas we found so far no IgE responses against HIV components (Gallerano et al., unpublished data).

The HIV microarray for monitoring the specificities and magnitudes of HIV-specific antibody responses during the course of disease and treatment

Next, we studied if the HIV microarray could be used to monitor HIV-specific IgG responses during the course of disease and treatment. For this purpose we analysed IgG reactivity towards micro-arrayed peptides/proteins of 15 HIV-infected African patients from whom sera were available at different time-points (i.e., 47 serum samples from different time points). In this set of experiments sera from 15 control serum samples and sample diluent alone were tested as negative controls. Interestingly, most of the HIV-infected patients preserved their antibody recognition patterns (i.e., specificities, levels) over time (Fig. S2†). For single cases specific antibody reactivities were detected only at certain time-points (e.g., Pat \#8: gp41; Pat \#9: 120/24, 41/11, REV/01; Pat \#12: envelope peptides, MA, CA, PR). Fig. 7 shows two of these examples (patients \#8, 9), which were analysed in relation to immunological, clinical and treatment parameters.

For patient \#8 (Fig. 7a) four serum samples, taken over a period of 21 months, were analysed. Despite drops of the CD4 counts at the times when the second and third blood samples were taken, the IgG recognition profiles remained almost unchanged and there were no strong alterations regarding the levels of IgG responses towards the tested peptides and antigens. Only a few changes were noted. For example, IgG levels towards $120 / 24$ and 41/02 decreased over time and 120/16-specific IgG levels went down in the second serum sample and increased in the third and fourth sample. gp41-specific IgG was only detectable in the
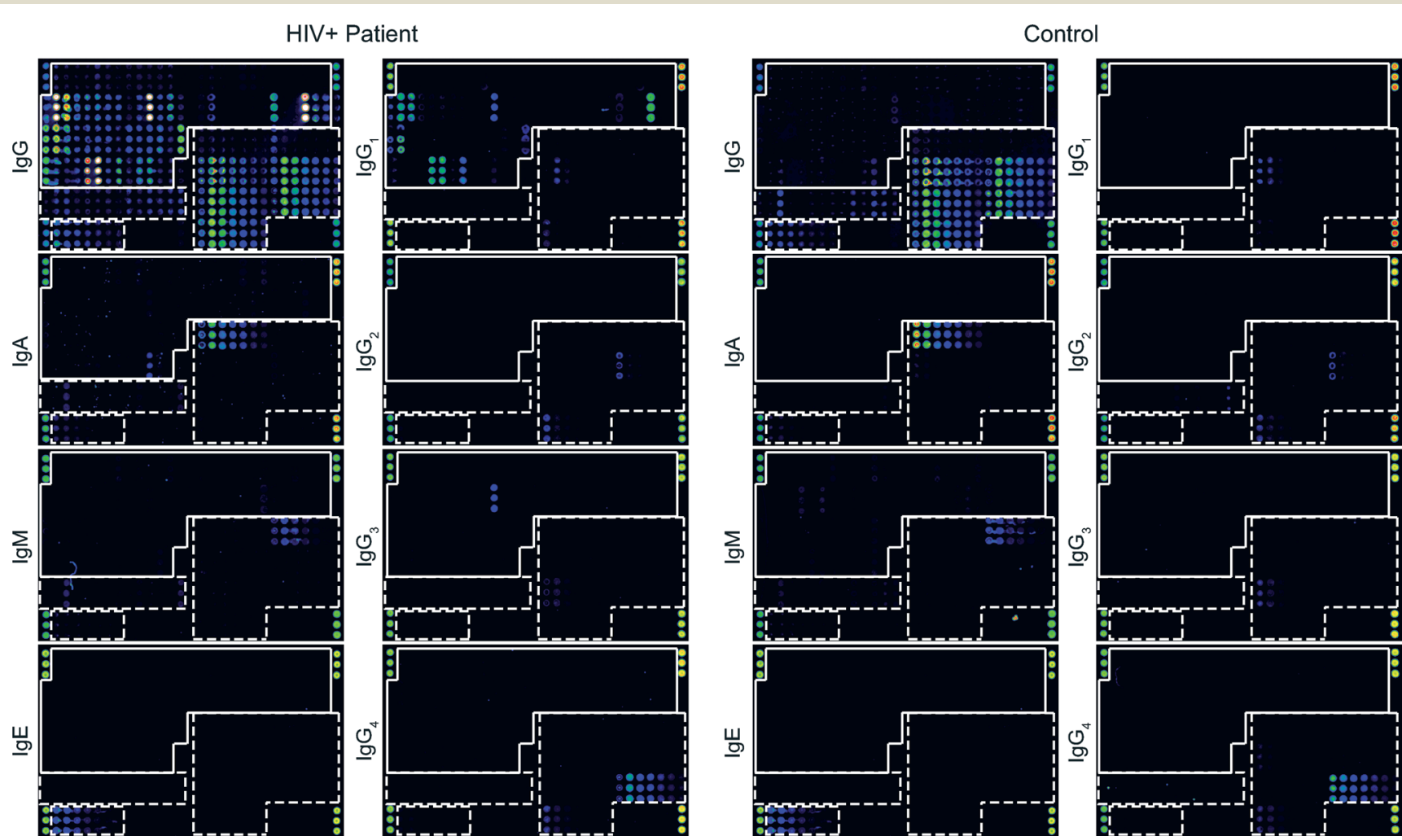

Fig. $6 \mathrm{IgG}$, IgA, IgM, IgE and $\lg _{1-4}$ reactivities to micro-arrayed antigens. Scan images obtained by testing serum from an HIV-positive subject (left panel) and control serum (right panel) for $\lg G$, IgA, IgM, IgE and $\lg G_{1-4}$ reactivity towards micro-arrayed HIV peptides/proteins and control proteins. Increasing fluorescence intensities from blue to red/white correspond to the amount of bound antibodies. The layout of spotted antigens is shown in Fig. 1c. HIV peptides and proteins are boxed and control antigens are surrounded by a broken line. 

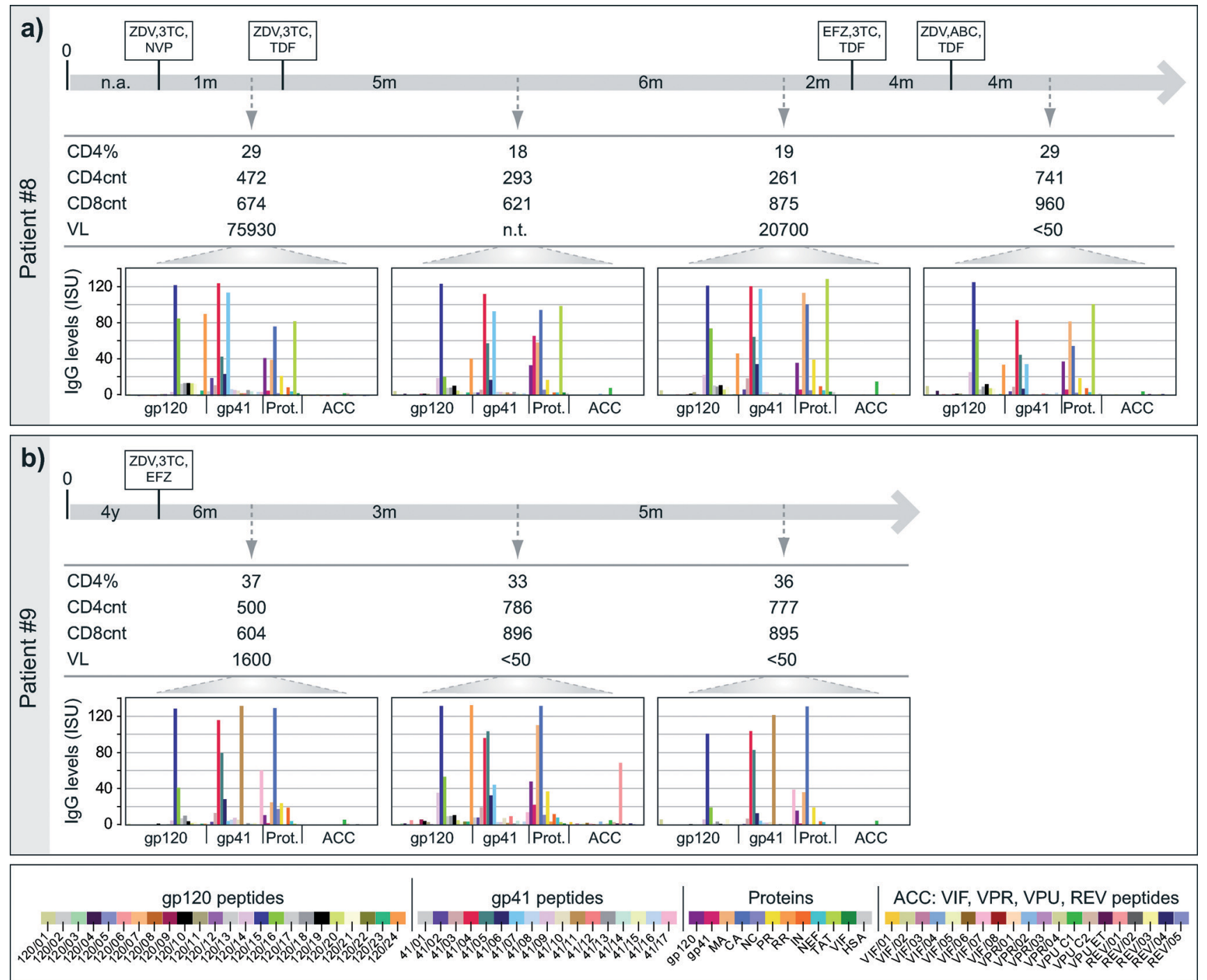

Fig. 7 Time course of IgG reactivities to micro-arrayed HIV proteins and peptides in sequential serum samples from HIV-infected individuals. Serum samples obtained from two HIV-infected individuals, (a) patient \#8 and (b) patient \#9, were obtained at different time points ( $x$-axes, with time intervals). Indicated are the time-points of infection (0), anti-retroviral treatment (HAART regimens boxed: Abacavir, ABC; Efavirenz, EFZ; Lamivudine, 3TC; Nevirapine, NVP; Tenofovir, TDF; Zidovudine, ZDV), time-points of serum collection (arrows), percentages of CD4 cells (CD4\%, CD4cnt/CD45cnt $\times 100), C D 4$ and CD8 counts (CD4cnt and CD8cnt, cells $\mathrm{mm}^{-3}$ ), viral loads (VL, copies $\mathrm{ml}^{-1}$, n.t., not tested) and IgG levels ( $y$-axes: ISU) towards gp120 peptides, gp41 peptides, HIV proteins and accessory protein-derived peptides (bottom line: colour code).

third serum sample but not in the others. In patient \#9 (Fig. 7b), who had a stable treatment response (CD4 counts $>500$ cells $\mathrm{mm}^{-3}$ and VL decreasing $<50$ copies $\mathrm{ml}^{-1}$ ), we also observed a rather conserved antibody recognition profile. Again, only a few changes were noted. For example, in the second serum sample IgG levels towards $41 / 11$ and $41 / 17$ decreased (60-fold and 4 -fold, respectively) and high IgG levels were measured towards 120/14, 120/24, 41/07, gp120, MA and REV/01, although IgG was absent or low to these peptides/proteins at the other time-points.

The results thus demonstrate that HIV microarray allows detecting changes of epitope specificity in longitudinal assessments in given individuals.

\section{Discussion}

We developed HIV chips containing six microarrays, on which a large panel of proteins and peptides of the HIV-1 clade C proteome were immobilized for the analysis of HIV-specific antibody responses. The miniaturized assay allowed the measurement of IgG, IgG subclass, IgM, IgA and IgE responses towards a broad panel of HIV peptides and proteins, with minimal amounts of spotted antigens (i.e., 50-200 fg), minute volumes of serum (i.e., $0.6 \mu \mathrm{l}$ for $\mathrm{IgG}_{\mathrm{G}} \mathrm{IgG}_{1}$, IgA, IgM; $3.0 \mu \mathrm{l}$ for $\mathrm{IgG}_{2-4}, 30 \mu \mathrm{l}$ for IgE measurements), consuming low amounts of detection antibodies (i.e., $0.03 \mu \mathrm{g}$ ) and in short assayduration (i.e. $<3 \mathrm{~h}$ ). To test $\operatorname{IgG}$ reactivity to the same 
72 HIV-derived components and a control component, immunoassays such as ELISA and Western-blot would require approximately $0.4 \mu \mathrm{g}$ of protein/peptide, 50-80 $\mu \mathrm{l}$ of serum (considering a serum dilution $1: 200$ ) and 0.6-1.0 $\mu \mathrm{g}$ detection antibody. With assay durations of 2-3 days for ELISA, only 20-80 tests per week could be performed manually by one person towards the same set of antigens in comparison to 600 tests per week that can be analysed by the microarray technology described here. Furthermore automated processing of a large number of chips is currently being developed.

The HIV microarray may well be used also for serological diagnosis of HIV infections but it must be born in mind, that currently available screening procedures that combine different antigen-antibody assays and nucleic acid based assays offer extremely high sensitivity and specificity. ${ }^{27-31}$ Nucleic acid-based tests and tests focusing on the p24 antigen are particularly important for testing when antibody production is not yet detectable in patients shortly after infection and when the host's immune system is compromised. ${ }^{32,33}$ Another focus in diagnostic testing is the discrimination of HIV-1 and HIV-2 infections ${ }^{33}$ and the availability of tests that can be used for point of care testing and in countries under difficult conditions where laboratory facilities are lacking and costs are an important issue. ${ }^{34,35}$

Fast and comprehensive immunoassays such as the HIV microarray may therefore address another increasing need of the scientific HIV-research community. Multiplex tests will be useful for the screening of large numbers of samples in prevalence, population studies and vaccine trials. In fact it has been shown that multiplex assays deciphering immune antibody signatures towards a large panel of HIV antigens and epitopes may allow identifying protective immune responses. ${ }^{9,36}$ One possibility to assess simultaneously antibody responses towards several antigens and epitopes as well as towards antigenic structures from different microorganisms is the use of various forms of microbeads containing different antigens. ${ }^{37-40}$ However, with bead technology only a limited number of different antigens can be tested whereas the use of microarrays allows testing simultaneously for much larger numbers of antigens.

The HIV microarray developed by us contained 147 different components, which may be further increased by number. We noted that the micro-arrayed HIV-1 clade $\mathrm{C}$ peptides and proteins not only allowed mapping of HIV-specific antibody recognition profiles both in HIV-infected patients from an African region where clade $\mathrm{C}$ is endemic, but also in patients from Europe where clade $\mathrm{B}$ predominates. At present our micro-array comprised only clade $\mathrm{C}$ peptides and proteins but it may be considered to expand the repertoire of spotted components to include also antigens and peptides from other strains in order to test if we can identify strain-specific antibody signatures. At present the chip contains structurally folded recombinant HIV proteins as well as unfolded peptides and thus allows detection of antibody responses towards conformational as well as sequential epitopes. It may be also considered to expand the antigen repertoire regarding carbohydrate epitopes and glycoproteins. We think that the HIV microarray is a suitable tool for the mapping of antibody responses towards HIV-derived peptides and also HIV recombinant proteins in large patient cohorts and trials and in populations from different geographic regions. The possibility to measure various isotypes and IgG-subclasses against a comprehensive set of HIV antigens and peptides in serum samples and other body fluids may also provide new information for the development of new therapeutic strategies. For example, the assessment of different Ig isotypes and IgG subclasses may be important because they are relevant for the effector functions of these antibodies and thus in virus defense (e.g., complement activation, ADCC, etc.). Several studies indicate that certain isotypes/subclass responses may be associated with infection control or bad prognosis. For example, protective effects were suggested for gp120-specific $\mathrm{IgG}_{3}$ in the RV144 vaccine trial $^{41}$ or for gp41-specific $\mathrm{IgG}_{2}$ antibody responses regarding persistence of long-term nonprogression. ${ }^{42} \mathrm{HIV}$-specific IgA responses are found in sera and mucous secretions of HIV-infected patients (e.g. genital secretions, saliva) and in breast milk of infected mothers. ${ }^{43,44}$ Micro-arrayed HIV components may therefore be interesting to study the fine specificities of these responses and to relate them to clinical findings.

First results from our study indicate that the HIV microarray can be used to detect changes of epitope specificity in longitudinal assessments in given individuals. Interestingly, we found changes in antibody recognition profiles even when plasma viral loads were undetectable. It is thus possible that the presence of HIV cellular reservoirs in anatomical compartments other than blood boosts antibody production and/or that long-lived plasma cells continuously secrete HIV-specific antibodies. ${ }^{45-48}$ Unfortunately detailed PCR data from the investigated subjects were not available for a comparison with the antibody signatures. However, any direct comparison of nucleic acid-based tests and tests measuring specific antibodies must be considered difficult because nucleic acid-based tests will measure already the presence of a microorganism whereas antibody-based tests reflect the host immune response against the microorganism.

In summary we believe that the HIV chip will be valuable for the analysis of isotype and subclass responses towards a comprehensive panel of HIV components and thus may be useful for gaining new insights into HIV-specific immune responses, for diagnosis and monitoring of treatment strategies.

\section{Conclusion}

The HIV chip offers a miniaturized platform containing a comprehensive set of antigens and peptides covering the HIV proteome for the assessment of the specificity and magnitude of HIV-specific IgG, IgG-subclass, IgA, IgM and IgE responses. We showed that the HIV microarray allows diagnosis as well as monitoring of HIV-specific antibody responses during the natural course of infection and treatment. The HIV 
multiplexed immunoassay will be particularly useful for the mining of complex protein and peptide-specific antibody signatures in populations, cohorts and vaccine trials.

\section{Conflict of interest}

DG, ES and RV are authors on a patent application regarding the use of clade C peptides/proteins for diagnosis of HIV infections. RV serves as a consultant for Biomay AG, Vienna, Austria, Thermofisher, Uppsala, Sweden and Fresenius Medical Care, Bad Homburg, Germany.

\section{Abbreviations}

$\begin{array}{ll}\text { a-huIg } & \text { anti-human Ig } \\ \text { AUC } & \text { area under the curve } \\ \text { BSA } & \text { bovine serum albumin } \\ \text { CA } & \text { capsid } \\ \text { ELISA } & \text { enzyme-linked immunosorbent assay } \\ \text { gp120 } & \text { glycoprotein 120 } \\ \text { gp41 } & \text { glycoprotein } 41 \\ \text { huIg } & \text { human immunoglobulin } \\ \text { HAART } & \text { highly-active anti-retroviral treatment } \\ \text { HSA } & \text { human serum albumin } \\ \text { IN } & \text { integrase } \\ \text { ISAC } & \text { immuno solid-phase allergen chip } \\ \text { ISU } & \text { ISAC standardized unit } \\ \text { MA } & \text { matrix } \\ \text { NC } & \text { nucleocapsid } \\ \text { NEF } & \text { negative factor } \\ \text { OD } & \text { optical density } \\ \text { PBS } & \text { phosphate buffered saline } \\ \text { PR } & \text { protease } \\ \text { REV } & \text { regulator of virion expression } \\ \text { ROC curve } & \text { receiver operating characteristic curve } \\ \text { RR } & \text { reverse transcriptase }+ \text { RNaseH } \\ \text { SD } & \text { standard deviation } \\ \text { TAT } & \text { trans-activator of transcription } \\ \text { VIF } & \text { virus infectivity factor } \\ \text { VPR } & \text { viral protein R } \\ \text { VPU } & \text { viral protein U } \\ & \end{array}$

\section{Acknowledgements}

The study was supported by a research grant from Biomay AG, Vienna, Austria and in part by the PhD program Inflammation and Immunity IAI of the Austrian Science Fund (FWF). We acknowledge the team of Phadia Austria GmbH, Part of Thermo Fisher Scientific ImmunoDiagnostics, Vienna, Austria for helping with the setup of chip-tests. We thank Margarete Focke-Tejkl and Luisa Schmidt for assisting with peptide synthesis and purification of recombinant NEF. We thank the Gammy City Lab Team and Kornelia Irger for helping with patient-care and routine diagnostic tests.

\section{References}

1 Global report: UNAIDS report on the global AIDS epidemic 2013. "UNAIDS/JC2502/1/E"- Revised and reissued, November 2013.

2 CDC. Monitoring selected national HIV prevention and care objectives by using HIV surveillance data - United States and 6 U.S. dependent areas 2011. HIV Surveillance Supplemental Report. 2013; 18(No.5). http://www.cdc.gov/ hiv/pdf/2011_Monitoring_HIV_Indicators_HSSR_FINAL.pdf. Accessed August 27, 2014.

3 CDC and Prevention and Association of Public Health Laboratories. Laboratory testing for the Diagnosis of HIV Infection: Updated Recommendations. 2014. Available at http://stacks.cdc.gov/view/cdc/23447. Published June 27, 2014. Accessed August 27, 2014.

4 F. Klein, H. Mouquet, P. Dosenovic, J. F. Scheid, L. Scharf and M. C. Nussenzweig, Science, 2013, 341, 1199-1204.

5 B. D. Walker and X. G. Yu, Nat. Rev. Immunol, 2013, 13, 487-498.

6 J. I. Lai, A. F. Licht, A. S. Dugast, T. Suscovich, I. Choi, C. Bailey-Kellogg, G. Alter and M. E. Ackerman, J. Virol., 2014, 88, 2799-2809.

7 A. W. Chung, M. Ghebremichael, H. Robinson, E. Brown, I. Choi, S. Lane, A. S. Dugast, M. K. Schoen, M. Rolland, T. J. Suscovich, A. E. Mahan, L. Liao, H. Streeck, C. Andrews, S. Rerks-Ngarm, S. Nitayaphan, M. S. de Souza, J. Kaewkungwal, P. Pitisuttithum, D. Francis, N. L. Michael, J. H. Kim, C. Bailey-Kellogg, M. E. Ackerman and G. Alter, Sci. Transl. Med., 2014, 6, 228ra238.

8 B. F. Haynes, P. B. Gilbert, M. J. McElrath, S. Zolla-Pazner, G. D. Tomaras, S. M. Alam, D. T. Evans, D. C. Montefiori, C. Karnasuta, R. Sutthent, H. X. Liao, A. L. DeVico, G. K. Lewis, C. Williams, A. Pinter, Y. Fong, H. Janes, A. DeCamp, Y. Huang, M. Rao, E. Billings, N. Karasavvas, M. L. Robb, V. Ngauy, M. S. de Souza, R. Paris, G. Ferrari, R. T. Bailer, K. A. Soderberg, C. Andrews, P. W. Berman, N. Frahm, S. C. De Rosa, M. D. Alpert, N. L. Yates, X. Shen, R. A. Koup, P. Pitisuttithum, J. Kaewkungwal, S. Nitayaphan, S. Rerks-Ngarm, N. L. Michael and J. H. Kim, N. Engl. J. Med., 2012, 366, 1275-1286.

9 R. Gottardo, R. T. Bailer, B. T. Korber, S. Gnanakaran, J. Phillips, X. Shen, G. D. Tomaras, E. Turk, G. Imholte, L. Eckler, H. Wenschuh, J. Zerweck, K. Greene, H. Gao, P. W. Berman, D. Francis, F. Sinangil, C. Lee, S. Nitayaphan, S. Rerks-Ngarm, J. Kaewkungwal, P. Pitisuttithum, J. Tartaglia, M. L. Robb, N. L. Michael, J. H. Kim, S. Zolla-Pazner, B. F. Haynes, J. R. Mascola, S. Self, P. Gilbert and D. C. Montefiori, PLoS One, 2013, 8, e75665.

10 R. Hiller, S. Laffer, C. Harwanegg, M. Huber, W. M. Schmidt, A. Twardosz, B. Barletta, W. M. Becker, K. Blaser, H. Breiteneder, M. Chapman, R. Crameri, M. Duchene, F. Ferreira, H. Fiebig, K. Hoffmann-Sommergruber, T. P. King, T. Kleber-Janke, V. P. Kurup, S. B. Lehrer, J. Lidholm, U. Muller, C. Pini, G. Reese, O. Scheiner, A. Scheynius, H. D. Shen, S. Spitzauer, R. Suck, I. Swoboda, W. Thomas, R. Tinghino, M. Van Hage-Hamsten, 
T. Virtanen, D. Kraft, M. W. Muller and R. Valenta, FASEB J., 2002, 16, 414-416.

11 W. H. Robinson, C. DiGennaro, W. Hueber, B. B. Haab, M. Kamachi, E. J. Dean, S. Fournel, D. Fong, M. C. Genovese, H. E. de Vegvar, K. Skriner, D. L. Hirschberg, R. I. Morris, S. Muller, G. J. Pruijn, W. J. van Venrooij, J. S. Smolen, P. O. Brown, L. Steinman and P. J. Utz, Nat. Med., 2002, 8, 295-301.

12 S. Gaseitsiwe, D. Valentini, S. Mahdavifar, I. Magalhaes, D. F. Hoft, J. Zerweck, M. Schutkowski, J. Andersson, M. Reilly and M. J. Maeurer, PLoS One, 2008, 3, e3840.

13 C. List, W. Qi, E. Maag, B. Gottstein, N. Muller and I. Felger, PLoS Neglected Trop. Dis., 2010, 4, e771.

14 S. T. Burgess, F. Kenyon, N. O'Looney, A. J. Ross, M. Chong Kwan, J. S. Beattie, J. Petrik, P. Ghazal and C. J. Campbell, Anal. Biochem., 2008, 382, 9-15.

15 R. P. Huang, Expert Rev. Proteomics, 2007, 4, 299-308.

16 J. Hemelaar, E. Gouws, P. D. Ghys and S. Osmanov, AIDS, 2011, 25, 679-689.

17 D. Gallerano, S. C. Devanaboyina, I. Swoboda, B. Linhart, I. Mittermann, W. Keller and R. Valenta, Amino Acids, 2011, 40, 981-989.

18 J. Edlmayr, K. Niespodziana, T. Popow-Kraupp, V. Krzyzanek, M. Focke-Tejkl, D. Blaas, M. Grote and R. Valenta, Eur. Respir. J., 2011, 37, 44-52.

19 S. Laffer, C. Lupinek, I. Rauter, M. Kneidinger, A. Drescher, J. H. Jordan, M. T. Krauth, P. Valent, F. Kricek, S. Spitzauer, H. Englund and R. Valenta, Allergy, 2008, 63, 695-702.

20 C. Harwanegg, S. Spitzauer, R. Valenta, M. W. Mueller and R. Hiller, Protein Microarrays, ed. M. Schena, Jones and Bartlett Publishers, Sudbury, MA, 2004, ch. 13, pp. 236-237.

21 E. P. Plueddemann, Silane coupling agents, Plenum Press, New York, 2nd edn, 1982.

22 HIV Assays: Operational Characteristics, Report 14, WHO, Geneva, 2004.

23 Laboratory Biosafety Manual, WHO, Geneva, 3rd edn, 2004.

24 C. Lupinek, E. Wollmann, A. Baar, S. Banerjee, H. Breiteneder, B. M. Broecker, M. Bublin, M. Curin, S. Flicker, T. Garmatiuk, H. Hochwallner, I. Mittermann, S. Pahr, Y. Resch, K. H. Roux, B. Srinivasan, S. Stentzel, S. Vrtala, L. N. Willison, M. Wickman, K. C. Lodrup-Carlsen, J. M. Anto, J. Bousquet, C. Bachert, D. Ebner, T. Schlederer, C. Harwanegg and R. Valenta, Methods, 2014, 66, 106-119.

25 S. C. Dalai, T. de Oliveira, G. W. Harkins, S. G. Kassaye, J. Lint, J. Manasa, E. Johnston and D. Katzenstein, AIDS, 2009, 23, 2523-2532.

26 J. Hemelaar, E. Gouws, P. D. Ghys and S. Osmanov, AIDS, 2011, 25, 679-689.

27 A. N. Fanmi, C. Ramière, J. C. Tardy and P. Andrè, Eur. J. Clin. Microbiol. Infect. Dis., 2013, 32, 425-430.

28 B. M. Branson, J. Acquired Immune Defic. Syndr., 2010, Suppl. 2, 102-105.

29 M. Salmona, S. Delarue, C. Delaugerre, F. Simon and S. Mavlin, J. Clin. Microbiol., 2014, 52, 103-107.

30 J. E. Levi, S. Wendel, D. T. Takaoka, I. C. Silva, J. P. Castro, M. A. Torezan-Filho, J. Ghaname, R. Gioachini, J. Brandao,
E. P. Landi, A. C. Teixera and E. L. Durigon, Rev. Inst. Med. Trop. Sao Paulo, 2007, 49, 171-176.

31 J. Dong, Y. Wu, H. Zhu, G. Li, M. Lv, D. Wu, X. Li, F. Zhu and H. Lv, Blood Transfus., 2014, 12, 172-179.

32 J. C. Gullett and F. S. Nolte, Clin. Chem., 2014, DOI: pil: clinchem.2014.22389.

33 M. W. Pandori and B. M. Branson, Expert Rev. Anti-Infect. Ther., 2010, 8, 631-633.

34 I. V. Jani, B. Meggi, N. Mabunda, A. Vubil, N. E. Sitoe, O. Tobaiwa, J. I. Quevedo, J. D. Lehe, O. Loquiha, L. Vojnov and T. F. Peter, J. Acquired Immune Defic. Syndr., 2014, 67, 1-4.

35 J. Singleton, J. L. Osborn, L. Lillis, K. Hawkins, D. Guelio, W. Price, R. Johns, K. Ebels, D. Boyle, B. Weigl and P. LaBarre, PLoS One, 2014, 9(11), e113693, DOI: 10.1371/ journal.pone.0113693.

36 S. Zolla-Pazner, A. deCamp, P. B. Gilbert, C. Williams, N. L. Yates, W. T. Williams, R. Howinton, Y. Fong, D. E. Morris, K. A. Soderberg, C. Irene, C. Reichman, A. Pinter, R. Parks, P. Pitisuttihum, J. Kaewkungwal, S. Rerks-Ngarm, S. Nitayaphan, C. Andrews, R. J. O'Connell, Z. Y. Yang, G. J. Nabel, J. H. Kim, N. L. Michael, D. C. Montefiori, H. X. Liao, B. E. Haynes and G. D. Tomaras, PLoS One, 2014, 9(2), e87572, DOI: 10.1371/journalpone.0087572.

37 L. Toellner, M. Fischlechner, B. Ferko, R. M. Grabherr and E. Donath, Clin. Chem., 2006, 52, 1575-1583.

38 K. A. Curtis, M. S. Kennedy, M. Charurat, A. Nasidi, K. Delaney, T. J. Spira and S. M. Owen, AIDS Res. Hum. Retroviruses, 2012, 28, 188-197.

39 R. L. Powell, I. Ouellette, R. W. Lindsay, C. L. Parks, C. R. King, A. B. McDermott and G. Morrow, BioRes. Open Access, 2013, 2, 171-178.

40 Y. Fujii, S. Kaeko, S. M. Nzou, M. Mwau, S. M. Njenga, C. Tanigawa, J. Kimotho, A. W. Mwangi, I. Kiche, S. Matsumoto, M. Niki, M. Osada-Oka, Y. Ichinose, M. Inoue, M. Itoh, H. Tachibana, K. Ishii, T. Tsuboi, L. M. Yoshida, D. Mondal, R. Haque, S. Hamano, M. Changoma, T. Hoshi, K. Kamo, M. Karama, M. Miura and K. Hirayama, PLoS Neglected Trop. Dis., 2014, 8(7), e3940, DOI: 10.14371/journalpntd.0003040.

41 N. L. Yates, H. X. Liao, Y. Fong, A. deCamp, N. A. Vandergrift, W. T. Williams, S. M. Alam, G. Ferrari, Z. Y. Yang, K. E. Seaton, P. W. Berman, M. D. Alpert, D. T. Evans, R. J. O'Connell, D. Francis, F. Sinangil, C. Lee, S. Nitayaphan, S. Rerks-Ngarm, J. Kaewkungwal, P. Pitisuttithum, J. Tartaglia, A. Pinter, S. Zolla-Pazner, P. B. Gilbert, G. J. Nabel, N. L. Michael, J. H. Kim, D. C. Montefiori, B. F. Haynes and G. D. Tomaras, Sci. Transl. Med., 2014, 6, 228 ra239.

42 V. Martinez, D. Costagliola, O. Bonduelle, N. N'go, A. Schnuriger, I. Theodorou, J. P. Clauvel, D. Sicard, H. Agut, P. Debre, C. Rouzioux and B. Autran, J. Infect. Dis., 2005, 191, 2053-2063.

43 G. D. Tomaras and B. F. Haynes, Curr. Opin. HIV AIDS, 2009, 4, 373-379.

44 J. Mabuka, R. Nduati, K. Odem-Davis, D. Peterson and J. Overbaugh, PLoS Pathog., 2012, 8, e1002739. 
45 V. Svicher, F. Ceccherini-Silberstein, A. Antinori, S. Aquaro and C. F. Perno, Curr. HIV/AIDS Rep., 2014, 11, 186-194.

46 R. A. Manz, A. Thiel and A. Radbruch, Nature, 1997, 388, 133-134.
47 A. Radbruch, G. Muehlinghaus, E. O. Luger, A. Inamine, K. G. Smith, T. Dorner and F. Hiepe, Nat. Rev. Immunol., 2006, 6, 741-750.

48 I. J. Amanna, N. E. Carlson and M. K. Slifka, N. Engl. J. Med., 2007, 357, 1903-1915. 